\title{
Effect of environmental contamination on female and male gametes - A lesson from bovines
}

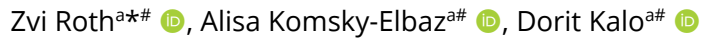 \\ ${ }^{a}$ Department of Animal Sciences, The Robert H. Smith Faculty of Agriculture, Food and Environment, The Hebrew University of \\ Jerusalem, Rehovot 76100, Israel
}

How to cite: Roth Z, Komsky-Elbaz A, Kalo D. Effect of environmental contamination on female and male gametes - A lesson from bovines. Anim Reprod. 2020;17(3):e20200041. https://doi.org/10.1590/1984-3143AR2020-0041

\begin{abstract}
Endocrine-disrupting compounds (EDCs) and foodborne contaminants are environmental pollutants that are considered reproductive toxicants due to their deleterious effects on female and male gametes. Among the EDCs, the phthalate plasticizers are of growing concern. In-vivo and in-vitro models indicate that the oocyte is highly sensitive to phthalates. This review summarizes the effects of di(2-ethylhexyl) phthalate and its major metabolite mono(2-ethyhexyl) phthalate (MEHP) on the oocyte. MEHP reduces the proportion of oocytes that fertilize, cleave and develop to the blastocyst stage. This is associated with negative effects on meiotic progression, and disruption of cortical granules, endoplasmic reticulum and mitochondrial reorganization. MEHP alters mitochondrial membrane polarity, increases reactive oxygen species levels and induces alterations in genes associated with oxidative phosphorylation. A carryover effect from the oocyte to the blastocyst is manifested by alterations in the transcriptomic profile of blastocysts developed from MEHP-treated oocytes. Among foodborne contaminants, the pesticide atrazine (ATZ) and the mycotoxin aflatoxin B1 (AFB1) are of high concern. The potential hazards associated with exposure of spermatozoa to these contaminants and their carryover effect to the blastocyst are described. AFB1 and ATZ reduce spermatozoa's viability, as reflected by a high proportion of cells with damaged plasma membrane; induce acrosome reaction, expressed as damage to the acrosomal membrane; and interfere with mitochondrial function, characterized by hyperpolarization of the membrane. ATZ and AFB1-treated spermatozoa show a high proportion of cells with fragmented DNA. Exposure of spermatozoa to AFB1 and ATZ reduces fertilization and cleavage rates, but not that of blastocyst formation. However, fertilization with AFB1- or ATZ-treated spermatozoa impairs transcript expression in the formed blastocysts, implying a carryover effect. Taken together, the review indicates the risk of exposing farm animals to environmental contaminants, and their deleterious effects on female and male gametes and the developing embryo.
\end{abstract}

Keywords: environmental contaminant, bovine, oocyte, spermatozoa, embryonic development.

\section{Introduction}

Female and male reproductive health can be affected by various environmental stressors. While much attention has been paid to the increase in ambient temperature, i.e., global warming, less attention has been given to environmental contamination and its consequences on animal fertility. Reproductive health can be affected by a variety of manmade environmental contaminants (Diamanti-Kandarakis et al., 2009) or foodborne toxins (Jin et al., 2015; Pflieger-Bruss et al., 2004), some of which are defined as endocrine-disrupting compounds (EDCs).

\footnotetext{
*Corresponding author: z.roth@mail.huji.ac.il

\#These authors contributed equally to this work.

Received: April 21, 2020. Accepted: June 23, 2020

Funding disclosure statement: ZR received funding for this research from the Environmental Health fund (EHF), Jerusalem, Israel.

Conflict of Interest: The authors have no conflict of interest to declare.
} 
EDCs are exogenous chemicals that can interfere with natural hormone activities, such as synthesis, secretion, transport, metabolism, and binding action, thereby impairing homeostasis, reproduction, and developmental processes. EDCs act by binding to nuclear receptors [e.g., aryl-hydrocarbon (dioxin) receptor, peroxisome proliferator-activated receptor family]. EDCs can also act via other mechanisms that are associated with endocrine and reproductive systems by binding to non-nuclear steroid hormone receptors (e.g., membrane estrogen and androgen receptors), non-steroid receptors (e.g., serotonin, dopamine and norepinephrine receptor) (Diamanti-Kandarakis et al., 2009).

Throughout the female's lifetime, follicular growth is characterized by recruitment of a cohort of primordial follicles into the pool of growing follicles from which a preovulatory follicle develops. In bovine, this course of follicular development is lengthy, taking approximately 180 days (Lussier et al., 1987). Therefore, exposure to environmental contaminants during early stages of follicular development might further affect the function of the follicle and its enclosed oocytes. EDCs act on the hypothalamic-pituitary-ovarian axis, and their effect on the female reproductive tract is therefore multifactorial in nature. The deleterious effect is expressed as ovarian failure, impaired follicular development, accelerated atresia and depletion of antral growing follicles, ovulation failure and impaired steroidogenesis. These, in turn, might lead to reduced fertility (Bhattacharya and Keating, 2012; Craig et al., 2011; Zama et al., 2016).

Similarly, spermatogenesis is a highly intricate and coordinated process that produces thousands of spermatozoa daily in the seminiferous tubules of the testes, which then pass through the epididymal caput (head) and corpus (body) and are stored in the cauda (tail) until ejaculation (Reyes-Moreno et al., 2002; Cornwall, 2014). In the bull, this process takes about 60 days (Staub and Johnson, 2018). During their passage through the epididymis compartments, the spermatozoa undergo extensive changes, which are completed in the female reproductive tract during the capacitation process. Given that spermatogenesis is also a lengthy process, spermatozoa are potentially exposed to a variety of environmental stressors at their different developmental stages. Indeed, epidemiological studies suggest an association between exposure to pesticides and semen quality (Swan et al., 2003). In that respect, the global decline in male fertility is mainly attributed to the exposure of spermatozoa to environmental EDCs, pharmaceutical products, pesticides and mycotoxins of food origin (Eze et al., 2018; Mann et al., 2020; Tavares et al., 2016).

The aim of the current review is to describe the risk associated with exposing farm animals to environmental contaminants. The review focuses on the effects of representative EDCs on female and male gametes, in particular the effects of the plasticizers phthalates on the oocyte, and of foodborne contaminants on the spermatozoa. A carryover effect from the gametes to the developed embryo is also discussed.

\section{Endocrine-disrupting compounds}

The list of EDCs consists of more than 80,000 heterogeneous chemicals that are used for numerous applications. Some of these are the polychlorinated biphenyls, polybrominated biphenyls, dioxins, plastics (bisphenol A;BPA), pesticides [methoxychlor, chlorpyrifos, atrazine (ATZ), dichlorodiphenyltrichloroethane (DDT)], fungicides (vinclozolin), pharmaceutical agents (diethylstilbestrol) and plasticizers (phthalates) (Diamanti-Kandarakis et al., 2009). The current section focuses on phthalates, a group of chemical reproductive toxicants, and discusses the mechanism by which phthalates impair oocyte competence and further, the formed embryo.

\section{Phthalates}

Phthalate esters have been widely used in manufacturing for about a century (Koch and Calafat, 2009). The annual production of phthalate is estimated at over 6 million tons worldwide, making these chemicals ubiquitous (Net et al., 2015a, b). More than 25 types of phthalates are used for commercial applications such as toys, vinyl flooring, wall covering, 
detergents, lubricating oils, food packaging, pharmaceuticals, blood bags and personal care products (Koch and Calafat, 2009). The top 10 are dimethyl phthalate, diethyl phthalate, dibutyl phthalate, diisobutyl phthalate, benzylbutyl phthalate, dicyclohexyl phthalate, di(2-ethylhexyl) phthalate (DEHP), di-n-octyl phthalate, di-isononyl phthalate, and di-isodecyl phthalate. With respect to animal exposure, in particular dairy cows, phthalates can be found in milking equipment such as milking pipes, liners, teat dip cups, food packing and silage wrap (Pure Strategies, 2018).

Among phthalates, DEHP is predominant, providing softness and flexibility to polyvinyl chloride products (ATSDR, 2002). DEHP does not bind covalently to the polyvinyl chloride polymer; it therefore leaches into the environment and is frequently found in the atmosphere, soil, sediment, and water sources (Bergé et al., 2013; Hongjun et al., 2013; Martine et al., 2013; Net et al., 2015b). It is estimated that humans are exposed to DEHP at around 1.7-52.1 $\mu \mathrm{g} / \mathrm{kg}$ body weight (BW) per day (McKee et al., 2004; Petersen and Breindahl, 2000). Infants are suggested to be at higher risk under certain circumstances (Kavlock et al., 2006). In the body, DEHP is metabolized into several metabolites, including mono(2-ethyl-5-hydroxyhexyl) phthalate (5OH-MEHP), mono(2-ethyl-5-carboxypentyl) phthalate (5cx-MEPP), mono(2-ethyl-5oxohexyl) phthalate (50xo-MEHP), mono[2-(carboxymethyl)hexyl] phthalate (2cx-MMHP), and mono(2-ethyhexyl) phthalate (MEHP) (Koch et al., 2005). According to the US Food and Drug Administration, the metabolites have more adverse and toxic effects than DEHP.

While the effects of phthalates on human health have been extensively studied (Benjamin et al., 2017; Hauser and Calafat, 2005), the magnitude and risk of exposure of domestic animals to phthalates is less known, most likely due to less awareness or concern. Nevertheless, recent studies have reported a deleterious effect of phthalates on animal health. In vivo studies in farm animals demonstrated the clearance pattern of DEHP. Oral administration to young male pigs of $1000 \mathrm{mg} / \mathrm{kg}$ BW DEHP resulted in a rapid increase in MEHP level (14 ng/L) in the blood with a half-life of $\sim 6 \mathrm{~h}$ (Ljungvall et al., 2004). Oral administration of DEHP to cows resulted in low levels of the metabolites 5OH-MEHP, MEHP, 5oxo-MEHP, 2cx-MMHP, and 5cx-MEPP were found in the milk, urine, and plasma samples of DEHP-treated cows, 20 days after DEHP administration (Kalo et al., 2015). A level of $\sim 20 \mathrm{nM}$ MEHP was detected in the follicular fluid aspirated from the DEHP-treated cows (Kalo et al., 2015). Similarly, a level of $\sim 10 \mathrm{nM}$ DEHP was recorded in equine follicular fluid (Marzano et al., 2019). Non-DEHP-originated metabolites such as monoethyl phthalate and monobutyl phthalate were also detected in the follicular fluid, presumably of environmental origin (Kalo et al., 2015). In addition, DEHP has been reported in bovine milk (Jarošová, 2006; Krejčíková and Jarošová, 2013) and fat tissue (Jarošová, 2006) and in ewe (Rhind et al., 2005) and swine tissues (Jarošová, 2006; Ljungvall et al., 2004).

\section{Effect of phthalates on female reproduction}

There is accumulating evidence associating the presence of phthalates in the environment with impaired reproduction and reduced female fertility. In women undergoing in-vitro fertilization treatments, the presence of DEHP and its metabolites in the urine has been associated with a low number of retrieved, matured and fertilized oocytes and a reduced number of high-quality embryos (Machtinger et al., 2018). Exposure of women to MEHP close to conception was associated with early pregnancy loss (Toft et al., 2011). High levels of MEHP and 50xo-MEHP in the urine have been associated with long gestation and interruption in parturition (Adibi et al., 2009). Tranfo et al. (2012) found a correlation between the level of DEHP metabolites in the urine and infertility, in both men and women. In mice, DEHP and MEHP deleteriously affected the ovarian pool of follicles, expressed as a reduction in the number of primordial and antral follicles (Hannon et al., 2016; Li et al., 2016; Moyer and Hixon, 2012; Niermann et al., 2015; Zhang et al., 2013). Chronic exposure of female mice, at implantation, to a high level of phthalate $(250 \mathrm{mg} / \mathrm{kg}$ BW) was associated with decreased pregnancy rates and increased miscarriage rates (Aldyreva et al., 1975). Exposure of female rats to high doses of DEHP (up to $2 \mathrm{~g} / \mathrm{kg}$ BW) altered estradiol concentration, inhibited follicular growth, disrupted the estrous cycle, and impaired ovulation (Davis et al., 1994; Gupta et al., 2010; 
Lovekamp-Swan and Davis, 2003). With respect to DEHP metabolites, studies in mice have reported that MEHP inhibits follicular growth and reduces estradiol production in antral follicles (Gupta et al., 2010; Wang et al., 2012). In vivo exposure of cows to $100 \mathrm{mg} / \mathrm{kg}$ DEHP per day for 3 days impairs the pattern of follicular development, decreases estradiol concentration and increase follicular pathologies (Kalo et al., 2015).

Taken together, it is becoming clear that both DEHP and MEHP are reproductive toxicants (Balabanič et al., 2011; Heudorf et al., 2007; Johnson et al., 2012; Kay et al., 2013).

\section{Effects of DEHP and MEHP on the oocyte}

Gathering evidence indicates that the oocyte is highly sensitive to phthalates. Oral administration of mice with $50-200 \mu \mathrm{L}$ of $2.56 \mu \mathrm{M}$ DEHP for 12 days reduced the number of mature oocytes, and decreased fertilization rate and embryonic development (Eimani et al., 2005). Exposing the ovaries of newborn mice, in vitro, to DEHP (10 or $100 \mu \mathrm{M})$ induced apoptosis, as it increased the mRNA expression of Bax, a proapoptotic factor, and the proportion of TUNEL-positive oocytes (Zhang et al., 2014). Oral administration of DEHP $(50,100$ or $200 \mu \mathrm{L}$ of $2.56 \mu \mathrm{M})$ to mice dose-dependently reduced the number of oocytes progressing to metaphase II. This was accompanied by a decrease in oocyte developmental competence, an increase in early apoptosis, and a decrease in the expression levels of the genes Ccna1, Asah1 and Pou5f1 (Absalan et al., 2017). Oral administration of $2000 \mu \mathrm{gg} / \mathrm{kg}$ BW DEHP per day to mice resulted in a lower number of retrieved oocytes, a higher number of unfertilized oocytes, a higher number of fragmented zygotes, and decreased embryonic development (Parra-Forero et al., 2019).

While much data have been reported for rodents, data from farm animals are limited. Acute exposure of equine oocytes to DEHP (12 and $1200 \mu \mathrm{M})$ induced apoptosis and increased reactive oxygen species (ROS) levels in the cumulus cells, but did not affect nuclear maturation (Ambruosi et al., 2011). In-vitro culture of equine oocytes with $0.12 \mu \mathrm{M}$ DEHP inhibited their nuclear maturation, and increased apoptosis and ROS levels in the surrounding cumulus cells (Ambruosi et al., 2011). On the other hand, exposure of porcine cumulus oocyte complexes (COCs) to extremely high doses of DEHP $(250 \mu \mathrm{M}$ to $5 \mathrm{mM})$ did not affect the proportion of oocytes with extruded polar body (Wang et al., 2016). Exposure of bovine COCs to $50 \mu \mathrm{M}$ DEHP during oocyte maturation did not affect their cleavage rate into 2- to 4-cell-stage embryos, but decreased blastocyst-formation rate (Grossman et al., 2012).

In-vitro exposure of bovine oocytes to MEHP $(50 \mu \mathrm{M})$ impaired nuclear maturation, reflected by a decreased proportion of oocytes that resumed meiosis and progressed to the metaphase II stage (Grossman et al., 2012; Kalo and Roth, 2015). In-vitro culturing of bovine oocytes in follicular fluid containing $\sim 20 \mathrm{nM}$ MEHP resulted in a low proportion of oocytes that resumed meiosis. In particular, a higher proportion of MEHP-treated oocytes were blocked in the telophase I stage (Figure 1A; Kalo et al., 2015). In support of this, exposure of COCs or denuded bovine oocytes to 5-100 $\mu \mathrm{M}$ MEHP increased the proportion of oocytes expressing a germinal vesicle stage nucleus by the end of culture, i.e., they did not resume meiosis (Anas et al., 2003). Similar findings were reported for bovine COCs cultured with a high concentration of MEHP $(75 \mu \mathrm{M})$ (Beker van Woudenberg et al., 2012) and for porcine COCs cultured with 50-100 $\mu \mathrm{M}$ MEHP (Zhang et al., 2018). 


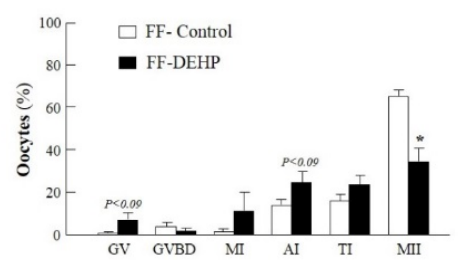

B

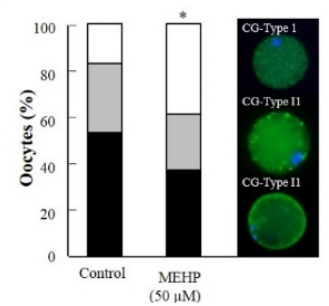

B'

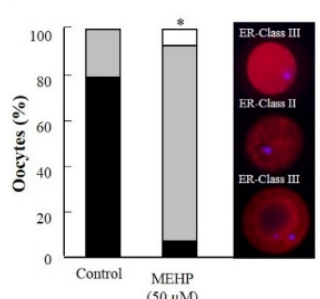

C

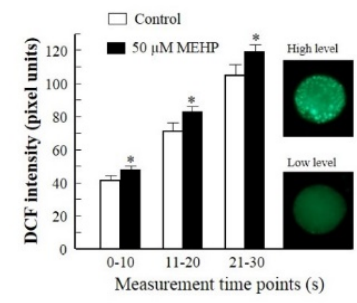

D

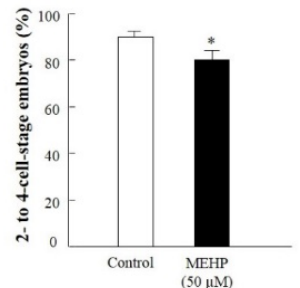

C'

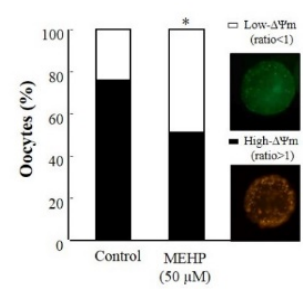

D'

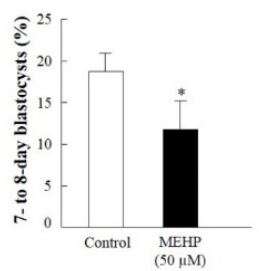

Figure 1. Effect of the EDC MEHP on bovine oocytes. (A) Nuclear maturation of oocytes cultured in follicular fluid (FF) aspirated from control (FF-control) and DEHP-treated (FF-DEHP) cows. Presented is the distribution of oocytes into meiotic stages: germinal vesicle (GV), GV breakdown (GVBD), metaphase I (MI), anaphase I (AI), telophase I (TI), and metaphase II (MII) (adapted with permission from Kalo et al., 2015). $\left(B, B^{\prime}\right)$ Cytoplasmic maturation is affected by MEHP. (B) Distribution of mature oocytes among three types of cortical granule (CG) patterns (fluorescein-conjugated peanut agglutinin [FITC-PNA] dye): CG-Type I (immature), CG-Type II (partially mature) and CG-Type III (fully mature). (B') Distribution of mature oocytes among three classes of endoplasmic reticulum (ER) pattern (red dye): ER-Class III (degenerative), ER-Class II (immature) and ER-Class I (fully mature). (C, $\left.C^{\prime}\right)$ Mitochondrial function is affected by MEHP. (C) ROS level expressed by dichlorofluorescein (DCF) fluorescence intensity, measured from 0-10,11-20 and 21-30 s in mature oocytes, and representative images of live oocyte stained with dichlorodihydrofluorescein diacetate $\left(\mathrm{H}_{2}\right.$ DCFDA) expressing low (bottom) or high (top) DCF fluorescence intensity. ( $\left.C^{\prime}\right)$ Proportion of oocytes with high- and low-polarized mitochondrial membrane $(\Delta \Psi \mathrm{m})$ along with representative images of live oocytes stained with MitoCapture mitochondrial apoptosis kit expressing high (red) and low (green) $\Delta \Psi \mathrm{m}$ (adapted with permission from Kalo and Roth, 2015). (D,D') Developmental competence of oocytes in-vitro matured without or with $50 \mu \mathrm{M}$ MEHP, further fertilized and cultured for 8 days. (D) Cleavage rate into 2- to 4-cell-stage embryos. (D') Blastocyst-formation rate (adopted with permission from Grossman et al., 2012).

One of the suggested mechanisms by which phthalates impair oocyte nuclear maturation is alterations in the CAMP-signaling pathway. An accurate cAMP level is required for chromatin transition, and synchronization between nuclear and cytoplasmic maturation (Gilchrist et al., 2011; Luciano et al., 2011). Microarray analysis of MEHP-treated bovine oocytes revealed alterations in seven transcripts associated with the CAMP-signaling pathway (Kalo et al., 2019). In rats, MEHP inhibited the accumulation of cAMP in Sertoli cells (Heindel and Chapin, 1989). In addition, exposure of rat granulosa cells to $100 \mu \mathrm{M}$ MEHP decreased progesterone production and follicle-stimulating hormone-induced CAMP accumulation (Treinen et al., 1990). MEHP-induced impairment of the cell cycle has also been suggested as a potential mechanism, because exposure of bovine oocytes to $50 \mu \mathrm{M}$ MEHP altered the expression level of CCNA2 (Grossman et al., 2012). In mice, oral administration of $100 \mu \mathrm{L}$ DEHP or MEHP $(2.56 \mu \mathrm{M})$ resulted in reduced expression of the pluripotency (Pou5f1), cell cycle (Ccna1) and apoptotic (Asah1) related genes (Absalan et al., 2017).

Recent studies have provided evidence that phthalates induce alterations in cytoplasmic maturation in association with reduced oocyte competence. The maturation process includes multiple activities that are highly important to the formation of a mature and fertilizable oocyte. These include organelle redistribution (mitochondria, endoplasmic reticulum, cortical granules and lipid droplets), cytoskeletal rearrangement, and cytoplasmic polyadenylation (Eppig, 1996; Ferreira et al., 2009). Culturing of bovine COCs with 50 MM MEHP altered oocyte cytoplasmic maturation, reflected by alterations in the reorganization of the mitochondria, cortical granules and endoplasmic reticulum (Figure 1B,B'; Kalo and Roth, 2015). Given the pivotal function of the mitochondria in early stages of embryonic development (Acton et al., 2004; Bavister and Squirrell, 2000; Thouas et al., 2004), MEHP-induced impairment in oocyte mitochondrial 
function is suggested to be one of the main mechanisms underlying reduced developmental competence (Roth, 2018). Alterations in mitochondrial distribution were associated with increased ROS levels and decreased mitochondrial membrane potential $(\Delta \Psi \mathrm{m})$ (Figure $1 \mathrm{C}, C^{\prime}$ : Kalo and Roth, 2015). In mice, oral treatment with DEHP (40 $\mu \mathrm{g} / \mathrm{kg}$ BW) increased ROS levels in the oocytes, along with disruption of mitochondrial function and reduction in ATP levels (Lu et al., 2019). In equine, an increase in ROS and ATP levels was recorded in oocytes that were exposed to $12 \mu \mathrm{M}$ DEHP (Ambruosi et al., 2011). Zhang et al. (2018) reported that in-vitro culturing of porcine COCs with $75 \mu \mathrm{M}$ MEHP results in increased ROS production.

Changes in mitochondrial function along with the increased levels of ROS might further lead to apoptosis. Culturing of bovine COCs with $50 \mu \mathrm{M}$ MEHP increased the proportion of apoptotic oocytes (TUNEL+) (Kalo and Roth, 2015) and was associated with alteration in the expression of ASAH1 gene encodes the acid ceramidase enzyme, an antiapoptotic factor (Grossman et al., 2012). In-depth transcript screening and proteomic analysis strongly support the oocyte transcripts' sensitivity to MEHP, since alterations in several genes associated with mitochondria and the apoptotic cascade have been reported (Kalo et al., 2019). In support of this, MEHP induced alterations in the expression of genes associated with mitochondrial function in bovine COCs (cytochrome bc1 complex; CYC1, Mitochondrially Encoded Cytochrome C Oxidase I ;MT-CO1 and ATP synthase subunit beta; ATP5B), mouse fetal oocytes (superoxide dismutase 1 ;Sod1 and NADH dehydrogenase 1; Nd1) and porcine COCS (SOD1 and Catalase; CAT) (Kalo and Roth, 2015; Bonilla and del Mazo, 2010; Zhang et al., 2018).

\section{Carryover effect of DEHP and MEHP from the oocyte to the embryo}

The early developing embryo, as well as the growing fetus, can also be exposed to phthalates during their growth in the uterus. In humans, DEHP and MEHP have been detected in maternal serum and cord blood, peritoneal fluid, meconium and amniotic fluid (Arbuckle et al., 2016; Huang et al., 2014; Latini et al., 2003; Silva et al., 2004). Oral administration of DEHP (10 mg/kg BW) to female mice on day 7 or 8 of gestation led to a high incidence of death or malformed fetuses, whereas exposure before or after these crucial days resulted in fewer defective fetuses (Yagi et al., 1980). Exposure of mice on day 8 of gestation to $1 \mathrm{~mL} / \mathrm{kg}$ BW MEHP resulted in skeletal abnormalities and fetal deaths (Tomita et al., 1982; Yagi et al., 1980). In-vitro culture of 8-day-old mouse embryos with DEHP and MEHP (100-1000 $\mu \mathrm{g} / \mathrm{mL})$ impaired their development and increased the proportion of malformed embryos (Sant et al., 2016).

Moreover, carryover effects from the oocyte to the developed embryo have been documented. Culturing of bovine COCs with either $50 \mu \mathrm{M}$ DEHP or MEHP resulted in reduced oocyte developmental competence, expressed as a lower cleavage rate and reduced blastocyst-formation rate (Figure 1D, D'; Grossman et al., 2012). In-vitro exposure of bovine oocytes to relatively low levels of MEHP (20-1000 nM) decreased their developmental competence, reflected by a low proportion of oocytes that fertilized, cleaved and developed to the blastocyst stage (Kalo and Roth, 2017). In-vitro maturation of oocytes in follicular fluid aspirated from DEHP-treated cows (i.e., containing $20 \mathrm{nM}$ MEHP) reduced cleavage and blastocyst-formation rates (Kalo et al., 2015). Blastocysts developed from MEHP-treated oocytes showed different expression patterns of genes involved in intracellular mechanisms such as pluripotency, apoptosis, and placental development (Kalo et al., 2019). Culturing of bovine oocytes with $50 \mu \mathrm{M}$ MEHP altered the levels of POU5F1 in 2-cell-stage embryos (Grossman et al., 2012). MEHP-induced impairment in POU5F1 and SOX2 transcript abundance which associated with pluripotency, was found in blastocysts developed from oocytes exposed to relatively low MEHP concentrations (Kalo and Roth, 2017), suggesting that these embryos are of inferior quality. In-vitro maturation of bovine oocytes with 20 nM MEHP induced a carryover effect on the transcriptomic profile of the developing embryo, expressed by the altered expression of 260 genes (Kalo et al., 2019). Direct exposure of mouse embryos to $100-1000 \mu \mathrm{g} / \mathrm{mL}$ MEHP (corresponding to 0.4-3.6 mM) impaired the expression of metabolic genes, in particular those related to the electron transport chain (Sant et al., 2016). In agreement with this, a 
carryover effect was also recorded in female mice treated with DEHP or MEHP, manifested in a reduction in the proportion of developing blastocysts (Absalan et al., 2017).

\section{Summary}

This section provides broad information on the direct and indirect effects of phthalates on ovarian function, oocyte maturation and embryonic developmental competence. Note that when the oocyte was exposed to MEHP, deleterious effects were further recorded in the developed embryos. In addition, phthalate-induced damage involves multiple mechanisms which might also be relevant to other EDCs.

\section{Foodborne contaminants}

A wide range of chemicals have been identified as foodborne contaminants that can be potentially found in food and water and might be consumed by humans and/or animals. These include pesticides and herbicides (ATZ, methoxychlor, chlorpyrifos, DDT) (Diamanti-Kandarakis et al., 2009). Among the most concerning foodborne contaminants are the naturally occurring toxins, such as mycotoxins, and specifically aflatoxins (El Khoury et al., 2019). The current section focuses on two representative foodborne contaminants-the mycotoxin aflatoxin B1 (AFB1) and the herbicide ATZ-and discusses their toxic effects on bovine spermatozoa which carry over to the developed embryo.

\section{Effect of foodborne contaminants on male reproduction}

Studies in occupationally exposed humans, as well as animals, have shown that pesticides may cause pathological changes in the male reproductive system, such as testicular damage, decreased spermatogenesis, and reduced semen quality (Zamkowska et al., 2018). Pesticides and certain toxins, including mycotoxins, may pass through the blood-testis barrier and negatively affect spermatogenesis (Ataman et al., 2014; Perry, 2008). Nevertheless, the direct effect of these foodborne contaminants on spermatozoa has been less studied, and the existing data are limited to basic parameters, such as spermatozoon concentration and motility. Moreover, the mechanism by which foodborne contaminants induce damage in spermatozoa is not fully understood.

Sperm fertilization potential depends on multiple factors. Among these are the integrity and functionality of sperm membranes, which indicate the sperm's viability and fertilization potential (Figure 2A; Komsky-Elbaz and Roth, 2018). 
A
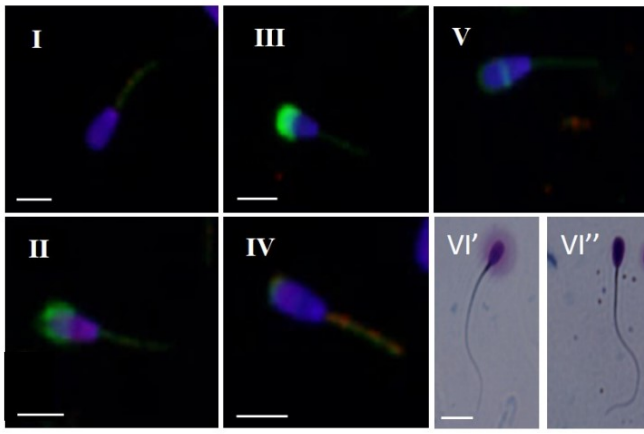

$\mathbf{B}$
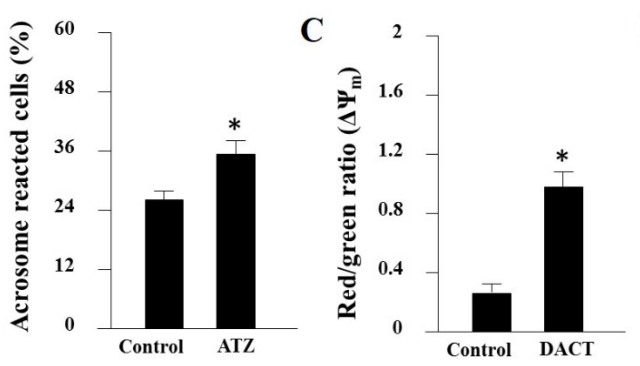

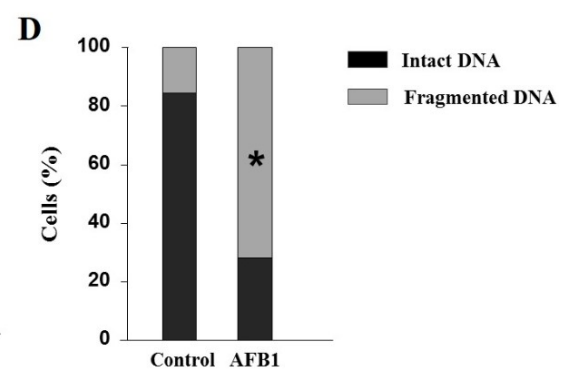

Figure 2. Effect of foodborne contaminants on spermatozoa. (A) Epifluorescence photomicrography of sperm cells stained with fluorescent probes: (I) live spermatozoon, nucleus stained with 4',6-diamidino-2-phenylindole (DAPl; blue); (II) dead spermatozoon with damaged plasma membrane (propidium iodide staining, purple) and damaged acrosome (fluorescein-conjugated Pisum sativum agglutinin [FITC-PSA] staining, green); (III) live spermatozoon with damaged acrosome membrane (green); (IV) acrosome-reacted sperm cell with residual upper staining (green) and high mitochondrial membrane potential stained by JC-1 (red); (V) acrosome-reacted sperm cell with residual equatorial FITC-PSA staining (green); (VI) spermatozoon DNA fragmentation determined by Halosperm kit: (VI') spermatozoon with intact DNA expresses large halo and ( $\mathrm{VI} \mathrm{I}^{\prime \prime}$ ) spermatozoon with fragmented DNA expresses small or no halo. Scale bars $=10 \mu \mathrm{M}$ (adopted with permission from Komsky-Elbaz and Roth, 2018). Spermatozoa were isolated from fresh ejaculate and incubated for $4 \mathrm{~h}$ without or with (B) $0.1 \mu \mathrm{M}$ ATZ, presented is the proportion of acrosome-reacted cells (FITC-PSA); (C) $1 \mu \mathrm{M} \mathrm{DACT,} \mathrm{mitochondrial} \mathrm{membrane} \mathrm{potential}(\Delta \Psi \mathrm{m})$ is presented as the mean proportion of red-stained (high potential) to green-stained (low potential) (JC-1) (adopted with permission from Komsky-Elbaz and Roth, 2017); (D) $10 \mu \mathrm{M}$ AFB1, spermatozoon DNA fragmentation determined by Halosperm kit (adopted with permission from Komsky-Elbaz and Roth, 2018). Data are presented as mean proportion $\pm \mathrm{SD}, * P<0.05$.

i. Plasma membrane Damage to plasma membrane integrity may reduce spermatozoa's viability and thus reduce their fertilization capacity (Komsky-Elbaz and Roth, 2017). Various EDCs, such as BPA and phthalates, have been reported to decrease spermatozoon viability in humans (Pant et al., 2011; Knez et al., 2014), and the herbicide, fenoxaprop-ethyl, in porcine (Betancourt et al., 2006).

ii. Acrosome integrity Disruption of spermatozoon acrosomal membrane integrity leads to loss of its ability to undergo acrosome reaction (AR), resulting in reduced competence to attach to and penetrate the zona pellucida and fertilize the oocyte. Pseudo-AR (i.e., a non-controlled event which occurs via unknown factors such as environmental contaminants) can also lead to loss of fertilization ability (Wiser et al., 2014).

iii. Mitochondrial function Alterations in mitochondrial function are associated with physiological dysfunction, including male infertility (Ramalho-Santos et al., 2009). In humans, loss of $\Delta \Psi \mathrm{m}$ is associated with low spermatozoon quality and caspase activation, which might eventually lead to apoptosis. Spermatozoa with altered $\triangle \Psi_{\mathrm{m}}$ generally have reduced fertilization potential and exhibit excess production of ROS (Espinoza et al., 2009). Various environmental compounds, such as EDCs, have been shown to induce cellular stress and lead to a transient increase in $\Delta \Psi \mathrm{m}$, i.e., hyperpolarization (Hüttemann et al., 2008), thereby leading to the generation of ROS (Saradha and Mathur, 2006). In turn, ROS can directly attack unsaturated fatty acids on the spermatozoon membrane, induce lipid peroxidation, damage 
membrane integrity, and eventually reduce the spermatozoa's fertilization potential (Lavranos et al., 2012). Mammalian spermatozoon membranes are rich in polyunsaturated fatty acids and thus are more susceptible to ROS attack, resulting in decreased sperm motility and viability, leading to infertility (Saradha and Mathur, 2006).

iv. DNA fragmentation The proportion of sperm with DNA fragmentation correlates with male fertility and is considered a practical parameter for characterizing semen quality (Sergerie et al., 2005). DNA molecules are a known target for various drugs, pesticides and toxic compounds (Ma et al., 2017; Virro et al., 2004). DNA damage was shown in subfertile males with increased BPA concentration in the urine (Meeker et al., 2010). In humans, increased DNA damage was documented after environmental and occupational exposure to the pesticide fenvalerate (Bian et al., 2004) and to a mixture of organophosphorous substances (SánchezPeña et al., 2004).

$v$. Epigenetic modifications The environmental effect on the gametes is not limited to the obvious physiological and genetic effects. Epigenetic modifications and DNA methylation in the germline can be altered by various environmental factors (Gely-Pernot et al., 2015; Siddeek et al., 2018). Changes in differentially methylated regions were recorded in spermatozoa exposed to the fungicide vinclozolin (Skinner et al., 2019). Alterations in spermatozoa's DNA-methylation profile were reported upon paternal exposure to PBA and phthalates (Manikkam et al., 2013).

\section{Effect of aflatoxins on the spermatozoa}

Aflatoxins are low-molecular-weight compounds produced mainly by the fungi Aspergillus flavus and Aspergillus parasiticus (Dai et al., 2017; Kew, 2013). Under humid conditions, these fungi grow on food grains, fruit and nuts, among others (Schenzel et al., 2012; Strosnider et al., 2006). Aflatoxin contamination can occur at any stage of the food chain (Verma, 2004), from preharvest to storage (limura et al., 2017; Shuaib et al., 2010). According to the US Food and Drug Administration the allowed amount of aflatoxins in human feed, is 4 to $30 \mathrm{ppb}(0.01-0.1 \mu \mathrm{M})$,

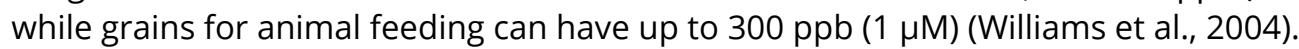

Of the aflatoxins, AFB1 is considered the most toxic to mammals, owing to its hepatotoxic, teratogenic, mutagenic and immunosuppressive properties (Raisuddin et al., 1993; Shen et al., 1994; Meissonnier et al., 2008). AFB1 is also defined as an EDC as it affects the cytochrome P450 enzymes, which are involved in steroid synthesis (Storvik et al., 2011). Consumption of AFB1 leads to rapid metabolism into several metabolites, including aflatoxin M1 (AFM1).

Aflatoxins are of great concern to public health because they accumulate in the body and can be found in edible tissues, such as liver and muscles, as well as in animal food products such as milk and eggs (Fan et al., 2015; Giovati et al., 2015; Monson et al., 2016; Rajkovic et al., 2007; Verma and Nair, 2001; Yuan et al., 2016). Moreover, aflatoxins have been found in human maternal breast milk, and maternal and cord blood (Shuaib et al., 2010), and can apparently enter the developing fetus in humans and animals (Verma, 2004). AFM1 can also be found in milk and in other dairy products. It is resistant to heat and not fully inactivated by pasteurization or sterilization (Becker-Algeri et al., 2016). In the USA and some Asian countries, the maximum residual level of AFM1 in milk is 0.5 ppb (Becker-Algeri et al., 2016). The Israeli Public Health Services - Food Control Services (2008-2012) have reported milk samples containing AFM1 at levels of 0.08-0.10 ppb.

Although aflatoxins are considered one of the major risk factors for infertility (Gong et al., 2016), there is limited information on their effect on the male gametes (i.e., spermatozoa), in particular following exposure to allowable regulated levels. Evaluation of semen samples revealed the presence of aflatoxins in $8 \%$ of the samples collected from fertile men, compared to $40 \%$ of those collected from infertile men (Ibeh et al., 1994). Human exposure to aflatoxin is associated with abnormal spermatozoon count and morphology, as well as reduced motility 
(Ibeh et al., 1994; Nduka et al., 2001). Administration of $50 \mu \mathrm{g} / \mathrm{kg}$ BW AFB1 daily to mice for 45 days led to upregulation of genes involved in cell differentiation, immunity and the extracellular matrix in the testes. These alterations led to disruption of androgen production in Leydig cells (Austin et al., 2012). In rats, a dose-dependent decrease in the number of spermatozoa that developed in the seminiferous tubules was observed following administration with 0.8-3.2 ppm AFB1 for 48 days (Hasanzadeh and Rezazadeh, 2013). Rats administered 10-50 $\mathrm{mg}$ AFB1 for 60 days showed decreased steroidogenesis, and reduced reproductive organ weight, sperm quantity, and sperm quality (Supriya et al., 2014). Oral administration of AFB1 (50 $\mathrm{\mu g} / \mathrm{kg}$ BW per day for 35 days) resulted in spermatotoxic effects on mouse epididymal sperm, expressed as reduced sperm concentration and motility and increased sperm abnormalities (Agnes and Akbarsha, 2003). Intramuscular injection of AFB1 (0.2-0.25 mL/day for 55 days) into male rats resulted in extrusion of the outer dense fibers and axonemal microtubule doublets of the sperm flagellum (Faisal et al., 2008a), suggesting negative effects on spermatozoa throughout the early stages of spermatogenesis.

In bovine, exposing spermatozoa to $10 \mu \mathrm{M}$ AFB1 for $4 \mathrm{~h}$ decreased their viability, but did not activate the AR. In addition, hyperpolarization of the mitochondrial membrane was documented (Komsky-Elbaz et al., 2018). Direct interaction of AFB1 with the cells' DNA, generating reversible non-covalent interactions, was demonstrated (Ma et al., 2017). It was suggested that binding of AFB1 to the DNA of mammalian spermatogenic cells (Sotomayor and Sega, 2000) and epididymal spermatozoa (Faisal et al., 2008b) interferes with normal spermatogenesis, resulting in the production of abnormal spermatozoa and reduced fertilization. Exposure of bovine spermatozoa to $10 \mu \mathrm{M}$ AFB1 significantly increased the proportion of DNA damage (Figure 2D; Komsky-Elbaz et al., 2018).

To date, very few studies have addressed the effect of mycotoxins on the male reproductive epigenome (El Khoury et al., 2019). In porcine, AFB1 at $50 \mu \mathrm{M}$ induced alterations in histone, DNA methylation and apoptosis, and increased ROS levels (Liu et al., 2015). A recent proteomics approach to explore possible mechanisms by which AFB1 induces alterations in spermatozoa revealed differential expression of multiple proteins related to several cellular pathways and biological processes, and associated with genetic and epigenetic processes (Komsky-Elbaz and Roth, 2019).

\section{Effect of ATZ on the spermatozoa}

ATZ is one of the best known chlorotriazine herbicides, extensively used to control growth of broadleaf and grassy weeds in agricultural crops (Severi-Aguiar and Silva-Zacarin, 2011). ATZ is considered a ubiquitous environmental contaminant, as it is frequently detected in ground and surface water, as a result of its mobility in the soil (Barr et al., 2007). ATZ has been banned for use in Europe since 2004, but is still utilized in about 70 countries, including US, Brazil, Argentina, Mexico, China, and Israel (LeBaron et al., 2008). Once it enters the body, ATZ is rapidly metabolized in the liver by cytochrome P450 enzymes into several metabolites, which are detected in the urine, serum and various tissues (Barr et al., 2007; Dooley et al., 2013; Ross et al., 2009); thus, an indirect effect of ATZ through its metabolites cannot be ruled out. In mammals, the major and most frequently detected metabolite is diaminochlorotriazine (DACT), shown to induce oxidative stress and disrupt endocrine function (Forgacs et al., 2013; jin et al., 2014). DACT forms covalent adducts with various proteins, presumably as a chemicalinduced toxicity step (Dooley et al., 2008).

Studies in humans have provided evidence for the transfer of trace amounts of ATZ to the circulation via the food chain (Diamanti-Kandarakis et al., 2009; Peighambarzadeh et al., 2011). For instance, ATZ has been detected in human amniotic fluid $(0.6 \mu \mathrm{g} / \mathrm{L})$ and urine $(0.1 \mu \mathrm{g} / \mathrm{L})$ (Bradman et al., 2003). Humans, wildlife, and domesticated animals can be exposed to ATZ via consumption of contaminated food or water, inhalation of pesticide spray, or absorption through the skin (Barr et al., 2007; Chevrier et al., 2011). Several studies have suggested that ATZ can alter reproductive functions, even at low, ecologically relevant doses $(0.1-3 \mu \mathrm{g} / \mathrm{L})$ (Abarikwu et al., 2010; Hayes, 2005; Jin et al., 2010). In amphibians, ATZ has a demasculinizing/feminizing effect (Hayes, 2005). Studies in rats have shown that ATZ elicits 
depletion of the antioxidant defense system in the testes, which in turn leads to oxidative stress (Abarikwu et al., 2010; Jin et al., 2010).

Gely-Pernot et al. (2015) reported that ATZ interferes with the process of meiosis in male mice. Interruption of meiosis, a key step in gametogenesis, may lead to the production of abnormal spermatozoa and reduced sperm quality, as found in ATZ-treated animals (Abarikwu et al., 2015; Feyzi-Dehkhargani et al., 2012). Supplementation of male goats with $15 \mathrm{mg} / \mathrm{kg}$ BW ATZ daily for 6 months impaired morphology, viability, $\Delta \Psi \mathrm{m}$, and cell lipid composition of ejaculated and epididymal spermatozoa (Komsky-Elbaz et al., 2019a). Daily administration of $25 \mathrm{mg} / \mathrm{kg}$ BW ATZ to mice impaired the production of spermatozoa by interfering with meiosis in the testes (Gely-Pernot et al., 2015). In rats, daily administration of $120 \mathrm{mg} / \mathrm{kg}$ BW ATZ depleted the antioxidant defense system (Abarikwu et al., 2010) and induced oxidative stress (Abdel Aziz et al., 2018) in the testes.

ATZ has been shown to decrease viability and increase the occurrence of pseudo-AR in bovine (Figure 2B; Komsky-Elbaz and Roth, 2017) and boar (Maravilla-Galván et al., 2009) spermatozoa. In this context, daily administration of $15 \mathrm{mg} / \mathrm{kg}$ BW ATZ to male goats for 6 months impaired the ejaculated spermatozoa's membrane composition, expressed as an increased proportion of saturated fatty acids and reduced proportion of polyunsaturated fatty acids, which were associated with spermatozoon quality (Komsky-Elbaz et al., 2019a). Mitochondrial membrane hyperpolarization was documented in ejaculated bovine spermatozoa after $4 \mathrm{~h}$ exposure to ATZ or DACT (Figure 2C; Komsky-Elbaz and Roth, 2017). In Drosophila spermatozoa, ATZ has been shown to affect mitochondrial electron transport (Hase et al., 2008). In addition, ATZ is suggested to inhibit mitochondrial function in human spermatozoa by binding to F1 F0-ATP synthase (Hase et al., 2008). In terms of practical aspects, i.e., artificial insemination, exposure to ATZ $(0.1-1 \mu \mathrm{M})$ or its metabolite, DACT (1-10 $\mu \mathrm{M})$, reduced spermatozoa's cryotolerance and survival post-thawing, by interfering with membrane integrity (Komsky-Elbaz et al., 2019b).

Epigenetic interference with spermatogenesis was documented in male mice (Gely-Pernot et al., 2015). Exposure of rat to $25 \mathrm{mg} / \mathrm{kg}$ BW/day ATZ was shown to promote epigenetic transgenerational inheritance, expressed by sperm differential DNA methylation regions over three generations (McBirney et al., 2017). Significant transgenerational differences in expression of genes involved in DNA methylation were reported in Medaka fish exposed to 5 or $50 \mu \mathrm{g} / \mathrm{L}$ ATZ (Cleary et al., 2019). Zebrafish larvae exposure to 3 ppb ATZ through embryogenesis lead to decreased expression of DNA methyltransferase and decreased DNA methylation levels (Wirbisky-Hershberger et al., 2017). Evaluation of the proteome of spermatozoa exposed to ATZ or DACT revealed differential expression of multiple proteins related to several cellular pathways and biological processes, associated with genetic and epigenetic processes (Komsky-Elbaz et al., unpublished data).

\section{Carryover effect of foodborne contaminants from the sperm to the embryo}

During fertilization, the spermatozoon delivers paternal components to the oocyte which are crucial for oocyte activation, zygote formation, and further embryonic development (Dogan et al., 2015). Thus, paternal exposure to environmental contaminants plays a critical role in the offspring's health (Siddeek et al., 2018). In-vitro fertilization of rat oocytes with epididymal sperm capacitated with AFB1 (2-16 ppb) resulted in significantly lower fertilization rates relative to fertilization with untreated sperm (Ibeh et al., 2000). In bovine, the proportion of oocytes that were fertilized and cleaved to 2- to 4-cell-stage embryos was lower after fertilization with spermatozoa exposed to $10 \mu \mathrm{M}$ AFB1 compared to non-treated spermatozoa, but blastocyst-formation rate was relatively fair (Komsky-Elbaz et al., 2018). One possible explanation is that although the spermatozoa were exposed to AFB1 through capacitation, fertilization was performed by those that had not been impaired.

The spermatozoa's contribution to the embryo is not limited to the paternal DNA; it also includes epigenetic marks on the DNA, as well as RNA and proteins that are transferred through fertilization (Castillo et al., 2018). About 108 sperm-originated proteins have been 
identified in the human blastocyst (Castillo et al., 2018), and these might be crucial for embryonic development and health (Oliva et al., 2015; Rando, 2012). It is also possible that the reduced cleavage rate reported for AFB1-treated spermatozoa expresses a delay in embryonic development rather than fertilization failure. In support of this assumption, it has been recently reported that sperm with DNA damage can fertilize the oocyte (Bungum et al., 2004). Moreover, soon after fertilization, a repair process begins in the oocyte (Uppangala et al., 2016), suggesting that the embryo can repair DNA damage of sperm origin. On the other hand, it has been reported that a high proportion of sperm with DNA damage is associated with altered metabolism in the developing blastocyst (Uppangala et al., 2016). These findings suggest that damaged DNA not only reduces sperm fertilization competence, but also negatively affects embryonic development (Ioannou et al., 2016) and increases the number of embryonic cells undergoing apoptosis (Simões et al., 2013). Exposure of spermatozoa of the marine invertebrate Galeolaria caespitosa to dibutyl phthalate inhibited fertilization and embryogenesis (Lu et al., 2017). Although sperm with damaged DNA can fertilize the oocyte, genomic instability in the developed embryo cannot be ruled out (Adiga et al., 2010). Evaluating the transcriptome profiles of blastocysts derived following in-vitro fertilization with AFB1-treated spermatozoa revealed a significantly different profile from that of the control, suggesting a carryover effect of AFB1 from the spermatozoa to the developing embryo (Komsky-Elbaz and Roth, unpublished data).

Traditional studies claim that inheritance from one generation to the next occurs solely through genetic information. However, there is increasing evidence of an important role for epigenetic factors in the transmission of certain phenotypes from parents to their offspring. Environmentally induced epigenetic alterations can be inherited through the male gametes (Wei et al., 2015) and might regulate gene expression at transcriptional as well as posttranscriptional levels in the early developing embryo (Castillo et al., 2018). For instance, paternal exposure to EDCs may cause alterations in the spermatozoa's RNA, and some of these changes might persist in the offspring (Uppangala et al., 2016). In mice, paternal prediabetes altered overall methylome patterns in spermatozoa, with a large portion of differentially methylated genes overlapping with genes of pancreatic islets in the offspring (Wei et al., 2014). Thus, it is highly possible that alterations in the transcriptomic profile of embryos derived after fertilization with AFB1-treated spermatozoa will include not only genetic but also epigenetic alterations. This point should be further evaluated.

\section{Summary}

There is a wide range of evidence for the potential hazard associated with exposure of spermatozoa to foodborne contaminants. The damage is already initiated in the testes during spermatogenesis, persists during the sperm's passage through the epididymis and finally, is expressed in the mature spermatozoa. Exposure of the spermatozoa to contaminants may also occur after ejaculation, in the female reproductive tract. The damage seems to be multifactorial in nature, involving alterations in the spermatozoa's membranes, DNA and proteome. Interestingly, different contaminants do not necessarily have the same effect on spermatozoa, suggesting different modes of action. Evidence of the damage in the spermatozoa carrying over to the developing embryo is of great concern, and warrants further investigation.

\section{General Summary}

This review provides a broad screening of the information on the effects of EDCs and foodborne contaminants on both the oocyte and spermatozoa (Figure 3). When the oocyte is exposed to MEHP, deleterious effects are further recorded in the developed embryos. Similarly, exposing spermatozoa to foodborne contaminants further affects the formed embryos. While this information is directly related to the presented environmental contaminants, these data might also be relevant to other EDCs. Exploring the risk associated with exposing animals to environmental contaminants might lead to better management for reproductive health preservation. 
Source

Cellular and
molecular
alteration

Functional

impairment

\section{Embryonic development}

\section{Embryo quality}

Food borne

contaminants

(ATZ, DACT, AFB1)

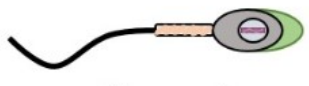

Spermatozoa

Membranes integrity;

Acrosome reaction;

Mitochondrial function;

Protein expression<smiles>[C]=C</smiles>

Fertilization

competence<smiles>c1ccccc1</smiles>

Paternal effect

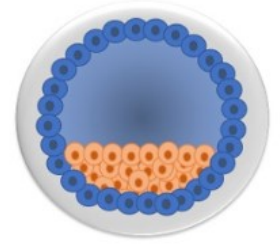

Alterations in gene expression profile
Endocrine disrupting chemicals

(Phthalates; MEHP, DEHP)

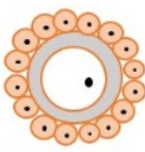

Cumulus oocyte complex

Nuclear maturation; Cytoplasmic maturation;

Gene expression;

Mitochondrial function;

Proteins expression

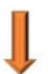

Oocyte developmental competence

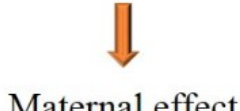

Maternal effect

Figure 3. Schematic illustration of the effects of EDCs and foodborne contaminants on female and male gametes. ATZ and AFB1 induce alterations in the spermatozoa. These include cellular and molecular alterations, which in turn impair fertilization competence. MEHP induces cellular and molecular alterations that affect oocyte developmental competence. Alterations in both male and female gametes are further expressed in the developed blastocyst.

\section{References}

Abarikwu SO, Adesiyan AC, Oyeloja TO, Oyeyemi MO, Farombi EO. Changes in sperm characteristics and induction of oxidative stress in the testis and epididymis of experimental rats by a herbicide, atrazine. Arch Environ Contam Toxicol. 2010;58(3):874-82. http://dx.doi.org/10.1007/s00244-0099371-2. PMid:19672647.

Abarikwu SO, Duru QC, Chinonso OV, Njoku R-C. Antioxidant enzymes activity, lipid peroxidation, oxidative damage in the testis and epididymis, and steroidogenesis in rats after co-exposure to atrazine and ethanol. Andrologia. 2015;48(5):548-57. http://dx.doi.org/10.1111/and.12478. PMid:26364937.

Abdel Aziz RL, Abdel-Wahab A, Abo El-Ela Fl, Hassan NE-HY, El-Nahass E-S, Ibrahim MA, Khalil AAY. Dosedependent ameliorative effects of quercetin and I-Carnitine against atrazine - induced reproductive toxicity in adult male Albino rats. Biomed Pharmacother. 2018;102:855-64. http://dx.doi.org/10.1016/j.biopha.2018.03.136. PMid:29710542.

Absalan F, Saremy S, Mansori E, Taheri Moghadam M, Eftekhari Moghadam AR, Ghanavati R. Effects of Mono-(2-Ethylhexyl) Phthalate and Di-(2-Ethylhexyl) Phthalate administrations on Oocyte Meiotic Maturation, Apoptosis and Gene Quantification in mouse model. Cell J. 2017;18(4):503-13. PMid:28042535.

Acton BM, Jurisicova A, Jurisica I, Casper RF. Alterations in mitochondrial membrane potential during preimplantation stages of mouse and human embryo development. Mol Hum Reprod. 2004;10(1):2332. http://dx.doi.org/10.1093/molehr/gah004. PMid:14665703. 
Adibi JJ, Hauser R, Williams PL, Whyatt RM, Calafat AM, Nelson H, Herrick R, Swan SH. Maternal urinary metabolites of Di-(2-Ethylhexyl) phthalate in relation to the timing of labor in a US multicenter pregnancy cohort study. Am J Epidemiol. 2009;169(8):1015-24. http://dx.doi.org/10.1093/aje/kwp001. PMid:19251754.

Adiga SK, Upadhya D, Kalthur G, Bola Sadashiva SR, Kumar P. Transgenerational changes in somatic and germ line genetic integrity of first-generation offspring derived from the DNA damaged sperm. Fertil Steril. 2010;93(8):2486-90. http://dx.doi.org/10.1016/j.fertnstert.2009.06.015. PMid:19591998.

Agnes VF, Akbarsha MA. Spermatotoxic effect of aflatoxin B(1) in the albino mouse. Food Chem Toxicol. 2003;41(1):119-30. http://dx.doi.org/10.1016/S0278-6915(02)00171-0. PMid:12453736.

Aldyreva MV, Klimova TS, Iziumova AS, Timofeevskaia LA. The effect of phthalate plasticizers on the generative function. Gig Tr Prof Zabol. 1975;(12):25-9. PMid:1213487.

Ambruosi B, Uranio M, Sardanelli A, Pocar P, Martino N, Parternoster M, Amati F, Dell'Aquila ME. In Vitro acute exposure to DEHP affects Oocyte Meiotic maturation, energy and oxidative stress parameters in a large animal model. PLoS One. 2011;6(11):e27452. http://dx.doi.org/10.1371/journal.pone.0027452. PMid:22076161.

Anas M-KI, Suzuki C, Yoshioka K, Iwamura S. Effect of mono-(2-ethylhexyl) phthalate on bovine oocyte maturation in vitro. Reprod Toxicol. 2003;17(3):305-10. http://dx.doi.org/10.1016/S08906238(03)00014-5. PMid:12759099.

Arbuckle TE, Fisher M, MacPherson S, Lang C, Provencher G, LeBlanc A, Hauser R, Feeley M, Ayotte P, Neisa A, Ramsay T, Tawagi G. Maternal and early life exposure to phthalates: The plastics and personal-care Products use in Pregnancy (P4) study. Sci Total Environ. 2016;551-552:344-56. http://dx.doi.org/10.1016/j.scitotenv.2016.02.022. PMid:26878646.

Ataman MB, Bucak MN, Coyan K. Esterified glucomannan improves aflatoxin-induced damage of sperm parameters during liquid storage of ram semen at 5 C. Cryobiology. 2014;68(3):405-10. http://dx.doi.org/10.1016/j.cryobiol.2014.03.007. PMid:24662029.

ATSDR. Toxicological profile for Di(2-ethylhexyl)phthalate (DEHP). Atlanta, GA: U.S. Department of Health and Human Services, Public Health Service; 2002.

Austin KJ, Cockrum RR, Jons AM, Alexander BM, Cammack KM. Renin mRNA is upregulated in testes and testicular cells in response to treatment with aflatoxin B1. Theriogenology. 2012;77:331-7.e1-7. http://dx.doi.org/10.1016/j.theriogenology.2011.08.004.

Balabanič D, Rupnik M, Klemenčič AK. Negative impact of endocrine-disrupting compounds on human reproductive health. Reprod Fertil Dev. 2011;23(3):403-16. http://dx.doi.org/10.1071/RD09300. PMid:21426858.

Barr DB, Panuwet P, Nguyen JV, Udunka S, Needham LL. Assessing exposure to atrazine and its metabolites using biomonitoring. Environ Health Perspect. 2007;115(10):1474-8. http://dx.doi.org/10.1289/ehp.10141. PMid:17938738.

Bavister BD, Squirrell JM. Mitochondrial distribution and function in oocytes and early embryos. Hum Reprod. 2000;15(Suppl 2):189-98. http://dx.doi.org/10.1093/humrep/15.suppl_2.189. PMid:11041524.

Becker-Algeri TA, Castagnaro D, Bortoli K, Souza C, Drunkler DA, Badiale-Furlong E. Mycotoxins in bovine milk and dairy products: A review. J Food Sci. 2016;81(3):R544-52. http://dx.doi.org/10.1111/17503841.13204. PMid:26799355.

Beker van Woudenberg A, Gröllers-Mulderij M, Snel C, Jeurissen N, Stierum R, Wolterbeek A. The bovine oocyte in vitro maturation model: A potential tool for reproductive toxicology screening. Reprod Toxicol. 2012;34(2):251-60. http://dx.doi.org/10.1016/j.reprotox.2012.05.098. PMid:22664270.

Benjamin S, Masai E, Kamimura N, Takahashi K, Anderson RC, Faisal PA. Phthalates impact human health: Epidemiological evidences and plausible mechanism of action. J Hazard Mater. 2017;340:36083. http://dx.doi.org/10.1016/j.jhazmat.2017.06.036. PMid:28800814.

Bergé A, Cladière M, Gasperi J, Coursimault A, Tassin B, Moilleron R. Meta-analysis of environmental contamination by phthalates. Environ Sci Pollut Res Int. 2013;20(11):8057-76. http://dx.doi.org/10.1007/s11356-013-1982-5. PMid:23917738.

Betancourt M, Reséndiz A, Fierro ECYR. Effect of two insecticides and two herbicides on the porcine sperm motility patterns using computer-assisted semen analysis (CASA) in vitro. Reprod Toxicol. 2006;22(3):508-12. http://dx.doi.org/10.1016/j.reprotox.2006.03.001. PMid:16713176.

Bhattacharya $P$, Keating AF. Impact of environmental exposures on ovarian function and role of xenobiotic metabolism during ovotoxicity. Toxicol Appl Pharmacol. 2012;261(3):227-35. http://dx.doi.org/10.1016/j.taap.2012.04.009. PMid:22531813. 
Bian Q, Xu LC, Wang SL, Xia YK, Tan LF, Chen JF, Song L, Chang HC, Wang XR. Study on the relation between occupational fenvalerate exposure and spermatozoa DNA damage of pesticide factory workers. Occup Environ Med. 2004;61(12):999-1005. http://dx.doi.org/10.1136/oem.2004.014597. PMid:15550606.

Bonilla E, del Mazo J. Deregulation of the Sod1 and Nd1 genes in mouse fetal oocytes exposed to mono(2-ethylhexyl) phthalate (MEHP). Reprod Toxicol. 2010;30(3):387-92. http://dx.doi.org/10.1016/j.reprotox.2010.04.008. PMid:20438828.

Bradman A, Barr DB, Claus Henn BG, Drumheller T, Curry C, Eskenazi B. Measurement of pesticides and other toxicants in amniotic fluid as a potential biomarker of prenatal exposure: A validation study. Environ Health Perspect. 2003;111(14):1779-82. http://dx.doi.org/10.1289/ehp.6259. PMid:14594631.

Bungum M, Humaidan P, Spano M, Jepson K, Bungum L, Giwercman A. The predictive value of sperm chromatin structure assay (SCSA) parameters for the outcome of intrauterine insemination, IVF and ICSI. Hum Reprod. 2004;19:1401-8. http://dx.doi.org/10.1093/humrep/deh280.

Castillo J, Jodar M, Oliva R. The contribution of human sperm proteins to the development and epigenome of the preimplantation embryo. Hum Reprod Update. 2018;24(5):535-55. http://dx.doi.org/10.1093/humupd/dmy017. PMid:29800303.

Chevrier C, Limon G, Monfort C, Rouget F, Garlantézec R, Petit C, Durand G, Cordier S. Urinary biomarkers of prenatal atrazine exposure and adverse birth outcomes in the PELAGIE birth cohort. Environ Health Perspect. 2011;119(7):1034-41. http://dx.doi.org/10.1289/ehp.1002775. PMid:21367690.

Cleary JA, Tillitt DE, vom Saal FS, Nicks DK, Claunch RA, Bhandari RK. Atrazine induced transgenerational reproductive effects in medaka (Oryzias latipes). Environ Pollut. 2019;251:639-50. http://dx.doi.org/10.1016/j.envpol.2019.05.013. PMid:31108297.

Cornwall GA. Role of posttranslational protein modifications in epididymal sperm maturation and extracellular quality control. Adv Exp Med Biol. 2014;759:159-80. http://dx.doi.org/10.1007/978-14939-0817-2_8. PMid:25030764.

Craig ZR, Wang W, Flaws JA. Endocrine-disrupting chemicals in ovarian function: effects on steroidogenesis, metabolism and nuclear receptor signaling. Reproduction. 2011;142(5):633-46. http://dx.doi.org/10.1530/REP-11-0136. PMid:21862696.

Dai Y, Huang K, Zhang B, Zhu L, Xu W. Aflatoxin B1-induced epigenetic alterations: an overview. Food Chem Toxicol. 2017;109(Pt 1):683-9. http://dx.doi.org/10.1016/j.fct.2017.06.034. PMid:28645871.

Davis BJ, Maronpot RR, Di Heindel JJ. -(2-ethylhexyl) phthalate suppresses estradiol and ovulation in cycling rats. Toxicol Appl Pharmacol. 1994;128(2):216-23. http://dx.doi.org/10.1006/taap.1994.1200. PMid:7940536.

Diamanti-Kandarakis E, Bourguignon J-P, Giudice LC, Hauser R, Prins GS, Soto AM, Zoeller RT, Gore AC. Endocrine-disrupting chemicals: an Endocrine Society scientific statement. Endocr Rev. 2009;30(4):293-342. http://dx.doi.org/10.1210/er.2009-0002. PMid:19502515.

Dogan S, Vargovic P, Oliveira R, Belser LE, Kaya A, Moura A, Sutovsky P, Parrish J, Topper E, Memili E. Sperm protamine-status correlates to the fertility of breeding bulls. Biol Reprod. 2015;92(4):92. http://dx.doi.org/10.1095/biolreprod.114.124255. PMid:25673563.

Dooley GP, Reardon KF, Prenni JE, Tjalkens RB, Legare ME, Foradori CD, Tessari JE, Hanneman WH. Proteomic analysis of diaminochlorotriazine adducts in wister rat pituitary glands and $L T 2$ rat pituitary cells 2008:21(4):844-51.

Dooley GP, Tjalkens RB, Hanneman WH. The atrazine metabolite diaminochlorotriazine suppresses LH release from murine $L \beta T 2$ cells by suppressing $\mathrm{GnRH}$-induced intracellular calcium transients. Toxicol Res (Camb). 2013;2(3):180-6. http://dx.doi.org/10.1039/c3tx20088d. PMid:24052811.

Eimani H, Dalman A, Sepehri H, Kazemi S, Hassani F, Rezazadeh M, Baharvand H, Shahverdi A, Samani RO. Effect of DEHP (Di-2-Ethyl Hexyl-phthalate) on resumption of meiosis and in-vitro maturation of mouse oocytes and development of resulting embryos. Yakhth Med J. 2005;7:56-61.

El Khoury D, Fayjaloun S, Nassar M, Sahakian J, Aad PY. Updates on the effect of mycotoxins on male reproductive efficiency in mammals. Toxins (Basel). 2019;11(9). http://dx.doi.org/10.3390/toxins11090515. PMid:31484408.

Eppig J. Coordination of nuclear and cytoplasmic oocyte maturation in eutherian mammals. Reprod Fertil Dev. 1996;8(4):485-9. http://dx.doi.org/10.1071/RD9960485. PMid:8870074. 
Espinoza JA, Paasch U, Villegas JV. Mitochondrial membrane potential disruption pattern in human sperm. Hum Reprod. 2009;24(9):2079-85. http://dx.doi.org/10.1093/humrep/dep120. PMid:19465458.

Eze UA, Huntriss J, Routledge MN, Gong YY. Toxicological effects of regulated mycotoxins and persistent organochloride pesticides: in vitro cytotoxic assessment of single and defined mixtures on MA-10 murine Leydig cell line. Toxicol Vitr. 2018;48:93-103. http://dx.doi.org/10.1016/j.tiv.2017.12.019. PMid:29307701.

Faisal K, Faridha A, Akbarsha MA. Induction of meiotic micronuclei in spermatocytes in vivo by aflatoxin B1: light and transmission electron microscopic study in Swiss mouse. Reprod Toxicol. 2008b;26:3039. http://dx.doi.org/10.1016/j.reprotox.2008.09.003.

Faisal K, Periasamy VS, Sahabudeen S, Radha A, Anandhi R, Akbarsha MA. Spermatotoxic effect of aflatoxin B1 in rat: extrusion of outer dense fibres and associated axonemal microtubule doublets of sperm flagellum. Reproduction. 2008a;135(3):303-10. http://dx.doi.org/10.1530/REP-07-0367. PMid:18299423.

Fan S, Li Q, Sun L, Du Y, Xia J, Zhang Y. Simultaneous determination of aflatoxin B 1 and M 1 in milk, fresh milk and milk powder by LC-MS/MS utilising online turbulent flow chromatography. Food Addit Contam Part A Chem Anal Control Expo Risk Assess. 2015;32(7):1175-84. http://dx.doi.org/10.1080/19440049.2015.1048311. PMid:25952817.

Ferreira EM, Vireque AA, Adona PR, Meirelles FV, Ferriani RA, Navarro PAAS. Cytoplasmic maturation of bovine oocytes: structural and biochemical modifications and acquisition of developmental competence. Theriogenology. 2009;71(5):836-48. http://dx.doi.org/10.1016/j.theriogenology.2008.10.023. PMid:19121865.

Feyzi-Dehkhargani S, Shahrooz R, Malekinejad H, Sadrkhanloo R-A. Atrazine in sub-acute exposure results in sperm DNA disintegrity and nuclear immaturity in rats. Vet Res Forum an Int Q J 2012;3:1926.

Forgacs AL, D'Souza ML, Huhtaniemi IT, Rahman NA, Zacharewski TR. Triazine Herbicides and Their Chlorometabolites Alter Steroidogenesis in BLTK1 Murine Leydig Cells. ToxSci 2013;134:155-67. https://doi.org/10.1093/toxsci/kft096.

Gely-Pernot A, Hao C, Becker E, Stuparevic I, Kervarrec C, Chalmel F, Primig M, Jégou B, Smagulova F. The epigenetic processes of meiosis in male mice are broadly affected by the widely used herbicide atrazine. BMC Genomics. 2015;16(1):885. http://dx.doi.org/10.1186/s12864-015-2095-y. PMid:26518232.

Gilchrist RB, Aktas H, Wheeler MB. Recent insights into oocyte - follicle cell interactions provide opportunities for the development of new approaches to in vitro maturation. Reprod Fertil Dev. 2011;23(1):23-31. http://dx.doi.org/10.1071/RD10225. PMid:21366977.

Giovati L, Magliani W, Ciociola T, Santinoli C, Conti S, Polonelli L. AFM1 in Milk: Physical, biological, and prophylactic methods to mitigate contamination. Toxins (Basel). 2015;7(10):4330-49. http://dx.doi.org/10.3390/toxins7104330. PMid:26512694.

Gong YY, Watson S, Routledge MN. Aflatoxin exposure and associated human health effects, a review of epidemiological studies. Food Saf. 2016;4(1):14-27. http://dx.doi.org/10.14252/foodsafetyfscj.2015026. PMid:32231900.

Grossman D, Kalo D, Gendelman M, Roth Z. Effect of di-(2-ethylhexyl) phthalate and mono-(2-ethylhexyl) phthalate on in vitro developmental competence of bovine oocytes. Cell Biol Toxicol. 2012;28(6):38396. http://dx.doi.org/10.1007/s10565-012-9230-1. PMid:22956148.

Gupta RK, Singh JM, Leslie TC, Meachum S, Flaws JA, Yao HH. C-(2-ethylhexyl) phthalate and mono-(2ethylhexyl) phthalate inhibit growth and reduce estradiol levels of antral follicles in vitro. Toxicol Appl Pharmacol. 2010;242(2):224-30. http://dx.doi.org/10.1016/j.taap.2009.10.011. PMid:19874833.

Hannon PR, Niermann S, Flaws JA. Acute exposure to Di(2-Ethylhexyl) phthalate in adulthood causes adverse reproductive outcomes later in life and accelerates reproductive aging in female mice. Toxicol Sci. 2016;150(1):97-108. http://dx.doi.org/10.1093/toxsci/kfv317. PMid:26678702.

Hasanzadeh S, Rezazadeh L. Effects of aflatoxin B1 on the growth processes of spermatogenic cell series in adult male rats. Comp Clin Pathol. 2013;22(4):555-62. http://dx.doi.org/10.1007/s00580-012-14452.

Hase Y, Tatsuno M, Nishi T, Kataoka K, Kabe Y, Yamaguchi Y, Ozawa N, Natori M, Handa H, Watanabe H. Atrazine binds to F1F0-ATP synthase and inhibits mitochondrial function in sperm. Biochem Biophys Res Commun. 2008;366(1):66-72. http://dx.doi.org/10.1016/j.bbrc.2007.11.107. PMid:18060860. 
Hauser R, Calafat AM. Phthalates and human health. Occup Environ Med. 2005;62(11):806-18. http://dx.doi.org/10.1136/oem.2004.017590. PMid:16234408.

Hayes TB. Welcome to the revolution: Integrative biology and assessing the impact of endocrine disruptors on environmental and public health. Integr Comp Biol. 2005;45(2):321-9. http://dx.doi.org/10.1093/icb/45.2.321. PMid:21676775.

Heindel JJ, Chapin RE. Inhibition of FSH-stimulated CAMP accumulation by mono(2-ethylhexyl) phthalate in primary rat Sertoli cell cultures. Toxicol Appl Pharmacol. 1989;97(2):377-85. http://dx.doi.org/10.1016/0041-008X(89)90342-6. PMid:2538009.

Heudorf U, Mersch-Sundermann V, Angerer J. Phthalates: toxicology and exposure. Int J Hyg Environ Health. 2007;210(5):623-34. http://dx.doi.org/10.1016/j.jjheh.2007.07.011. PMid:17889607.

Hongjun Y, Wenjun X, Qing L, Jingtao L, Hongwen Y, Zhaohua L. Distribution of phthalate esters in topsoil: a case study in the Yellow River Delta, China. Environ Monit Assess. 2013;185(10):8489-500. http://dx.doi.org/10.1007/s10661-013-3190-7. PMid:23609921.

Huang Y, Li J, Garcia JM, Lin H, Wang Y, Yan P, Wang L, Tan Y, Luo J, Qiu Z, Chen JA, Shu W. Phthalate levels in cord blood are associated with preterm delivery and fetal growth parameters in chinese women. PLoS One. 2014;9(2):e87430. http://dx.doi.org/10.1371/journal.pone.0087430. PMid:24503621.

Hüttemann M, Lee I, Pecinova A, Pecina P, Przyklenk K, Doan JW. Regulation of oxidative phosphorylation, the mitochondrial membrane potential, and their role in human disease.J Bioenerg Biomembr. 2008;40(5):445-56. http://dx.doi.org/10.1007/s10863-008-9169-3. PMid:18843528.

Ibeh IN, Saxena DK, Uraih N. Toxicity of aflatoxin: Effects on spermatozoa, oocytes, and in vitro fertilization. J Environ Pathol Toxicol Oncol. 2000;19(4):357-61. PMid:11213017.

Ibeh IN, Uraih N, Ogonar JI. Dietary exposure to aflatoxin in human male infertility in Benin City, Nigeria. Int J Fertil Menopausal Stud. 1994;39(4):208-14. PMid:7951403.

limura K, Furukawa T, Yamamoto T, Negishi L, Suzuki M, Sakuda S. The mode of action of Cyclo(I-Ala-IPro) in Inhibiting Aflatoxin Production of Aspergillus flavus. Toxins (Basel). 2017;9(7):219. http://dx.doi.org/10.3390/toxins9070219. PMid:28704973.

Ioannou D, Miller D, Griffin DK, Tempest HG. Impact of sperm DNA chromatin in the clinic. J Assist Reprod Genet. 2016;33(2):157-66. http://dx.doi.org/10.1007/s10815-015-0624-x. PMid:26678492.

Jarošová A. Phthalic acid esters (PAEs) in the Food Chain. Czech J Food Sci. 2006;24(5):223-31. http://dx.doi.org/10.17221/3318-CJFS.

Jin Y, Lin X, Miao W, Wang L, Wu Y, Fu Z. Oral exposure of pubertal male mice to endocrine-disrupting chemicals alters fat metabolism in adult livers. Environ Toxicol. 2015;30(12):1434-44. http://dx.doi.org/10.1002/tox.22013. PMid:24916741.

Jin Y, Wang L, Chen G, Lin X, Miao W, Fu Z. Exposure of mice to atrazine and its metabolite diaminochlorotriazine elicits oxidative stress and endocrine disruption. Environ Toxicol Pharmacol. 2014;37(2):782-90. http://dx.doi.org/10.1016/j.etap.2014.02.014. PMid:24632104.

Jin Y, Zhang X, Shu L, Chen L, Sun L, Qian H, Liu W, Fu Z. Oxidative stress response and gene expression with atrazine exposure in adult female zebrafish (Danio rerio). Chemosphere. 2010;78(7):846-52. http://dx.doi.org/10.1016/j.chemosphere.2009.11.044. PMid:20036412.

Johnson KJ, Heger NE, Boekelheide K. Of mice and men (and rats): phthalate-induced fetal testis endocrine disruption is species-dependent. Toxicol Sci. 2012;129(2):235-48. http://dx.doi.org/10.1093/toxsci/kfs206. PMid:22700540.

Kalo D, Hadas R, Furman O, Ben-Ari J, Maor Y, Patterson DG, Tomey C, Roth Z. Carryover effects of acute DEHP exposure on ovarian function and oocyte developmental competence in lactating cows. PLoS One. 2015;10(7):e0130896. http://dx.doi.org/10.1371/journal.pone.0130896. PMid:26154164.

Kalo D, Roth Z. Effects of mono(2-ethylhexyl)phthalate on cytoplasmic maturation of oocytes-the bovine model. Reprod Toxicol. 2015;53:141-51. http://dx.doi.org/10.1016/j.reprotox.2015.04.007. PMid:25900598.

Kalo D, Roth Z. Low level of mono(2-ethylhexyl) phthalate reduces oocyte developmental competence in association with impaired gene expression. Toxicology. 2017;377:38-48. http://dx.doi.org/10.1016/j.tox.2016.12.005. PMid:27989758.

Kalo D, Vitorino Carvalho A, Archilla C, Duranthon V, Moroldo M, Levin Y, Kupervaser M, Smith Y, Roth Z. Mono(2-ethylhexyl) phthalate (MEHP) induces transcriptomic alterations in oocytes and their derived blastocysts. Toxicology. 2019;421:59-73. http://dx.doi.org/10.1016/j.tox.2019.04.016. PMid:31059758. 
Kavlock R, Barr D, Boekelheide K, Breslin W, Breysse P, Chapin R, Gaido K, Hodgson E, Marcus M, Shea K, Williams P. NTP-CERHR Expert Panel Update on the Reproductive and Developmental Toxicity of di(2ethylhexyl) phthalate. Reprod Toxicol. 2006;22(3):291-399. http://dx.doi.org/10.1016/j.reprotox.2006.04.007. PMid:17068859.

Kay VR, Chambers C, Foster WG. Reproductive and developmental effects of phthalate diesters in females. Crit Rev Toxicol. 2013;43(3):200-19. http://dx.doi.org/10.3109/10408444.2013.766149. PMid:23405971.

Kew MC. Aflatoxins as a cause of hepatocellular carcinoma. J Gastrointestin Liver Dis. 2013;22(3):305-10. PMid:24078988.

Knez J, KranvogI R, Breznik BP, Vončina E, Vlaisavljević V. Are urinary bisphenol A levels in men related to semen quality and embryo development after medically assisted reproduction? Fertil Steril. 2014;101(1):215-221.e5. http://dx.doi.org/10.1016/j.fertnstert.2013.09.030. PMid:24182411.

Koch HM, Bolt HM, Preuss R, Angerer J. New metabolites of di(2-ethylhexyl)phthalate (DEHP) in human urine and serum after single oral doses of deuterium-labelled DEHP. Arch Toxicol. 2005;79(7):367-76. http://dx.doi.org/10.1007/s00204-004-0642-4. PMid:15700144.

Koch HM, Calafat AM. Human body burdens of chemicals used in plastic manufacture. Philos Trans R Soc Lond B Biol Sci. 2009;364(1526):2063-78. http://dx.doi.org/10.1098/rstb.2008.0208. PMid:19528056.

Komsky-Elbaz A, Roth Z. Effect of the herbicide atrazine and its metabolite DACT on bovine sperm quality. Reprod Toxicol. 2017;67:15-25. http://dx.doi.org/10.1016/j.reprotox.2016.11.001. PMid:27836535.

Komsky-Elbaz A, Roth Z. Fluorimetric techniques for the assessment of sperm membranes. J. Vis. Exp. 2018(141), e58622. http://dx.doi.org/10.3791/58 622.

Komsky-Elbaz A, Saktsier M, Roth Z. Aflatoxin B1 impairs sperm quality and fertilization competence. Toxicology. 2018;393:42-50. http://dx.doi.org/10.1016/j.tox.2017.11.007. PMid:29113834.

Komsky-Elbaz A, Roth Z. Atrazine-induced DNA fragmentation in bovine spermatozoa is associated with alterations in the transcriptome profile of in-vitro-derived embryos. 2019. In: Abstracts of the 35th Annual Meeting of the Association of Embryo Technology in Europe (AETE); 2019 Sept 13-14; Murcia, Spain. Murcia: AETE.

Komsky-Elbaz A, Saktsier M, Biran D, Argov-Argaman N, Azaizeh H, Landau YS, Roth Z. Atrazine-induced toxicity in goat spermatozoa is alleviated to some extent by polyphenol-enriched feed. Chemosphere. 2019a;236:124858. http://dx.doi.org/10.1016/j.chemosphere.2019.124858. PMid:31549674.

Komsky-Elbaz A, Zubov A, Roth Z. Effect of the herbicide atrazine and its major metabolite, DACT, on bovine sperm cryotolerance. Theriogenology. 2019b;140:117-23. http://dx.doi.org/10.1016/j.theriogenology.2019.08.026. PMid:31473494.

Krejčíková M, Jarošová A. Phthalate in cow milk depending on the method of milking. Medelnet [serial on the Internet]. 2013:592-6. [cited 2020 June 23]. Available from: http://mnet.mendelu.cz/mendelnet2013/articles/44_krejcikova_795.pdf

Latini G, De Felice C, Presta G, Del Vecchio A, Paris I, Ruggieri F, Mazzeo P. In utero exposure to di-(2ethylhexyl)phthalate and duration of human pregnancy. Environ Health Perspect. 2003;111(14):17835. http://dx.doi.org/10.1289/ehp.6202. PMid:14594632.

Lavranos G, Balla M, Tzortzopoulou A, Syriou V, Angelopoulou R. Investigating ROS sources in male infertility: a common end for numerous pathways. Reprod Toxicol. 2012;34(3):298-307. http://dx.doi.org/10.1016/j.reprotox.2012.06.007. PMid:22749934.

LeBaron HM, McFarland JE, Burnside OC. The Triazine Herbicides. Amsterdam: Elsevier; 2008. https://doi.org/10.1016/B978-044451167-6.50004-0.

Li L, Liu J-C, Lai F-N, Liu H-Q, Zhang X-F, Dyce PW, Shen W, Chen H. Di (2-ethylhexyl) Phthalate Exposure Impairs Growth of Antral Follicle in Mice. PLoS One. 2016;11(2):e0148350. http://dx.doi.org/10.1371/journal.pone.0148350. PMid:26845775.

Liu J, Wang Q-C, Han J, Xiong B, Sun S-C. Aflatoxin B1 is toxic to porcine oocyte maturation. Mutagenesis. 2015;30(4):527-35. http://dx.doi.org/10.1093/mutage/gev015. PMid:25778688.

Ljungvall K, Tienpont B, David F, Magnusson U, Törneke K. Kinetics of orally administered di(2-ethylhexyl) phthalate and its metabolite, mono(2-ethylhexyl) phthalate, in male pigs. Arch Toxicol. 2004;78(7):384-9. http://dx.doi.org/10.1007/s00204-004-0558-z. PMid:15022035.

Lovekamp-Swan T, Davis BJ. Mechanisms of phthalate ester toxicity in the female reproductive system. Environ Health Perspect. 2003;111(2):139-45. http://dx.doi.org/10.1289/ehp.5658. PMid:12573895. 
Lu Y, Lin M, Aitken RJ. Exposure of spermatozoa to dibutyl phthalate induces abnormal embryonic development in a marine invertebrate Galeolaria caespitosa (Polychaeta: serpulidae). Aquat Toxicol. 2017;191:189-200. http://dx.doi.org/10.1016/j.aquatox.2017.08.008. PMid:28843738.

Lu Z, Zhang C, Han C, An Q, Cheng Y, Chen Y, Chen Y, Meng R, Zhang Y, Su J. Plasticizer Bis(2-ethylhexyl) Phthalate causes meiosis defects and decreases fertilization ability of mouse oocytes in vivo. J Agric Food Chem. 2019;67(12):3459-68. https://doi.org/10.1021/acs.jafc.9b00121.

Luciano AM, Franciosi F, Modina SC, Lodde V. Gap junction-mediated communications regulate chromatin remodeling during bovine oocyte growth and differentiation through cAMP-Dependent Mechanism(s). Biol Reprod. 2011;85(6):1252-9. http://dx.doi.org/10.1095/biolreprod.111.092858. PMid:21816847.

Lussier JG, Matton P, Dufour JJ. Growth rates of follicles in the ovary of the cow. J Reprod Fertil. 1987;81(2):301-7. http://dx.doi.org/10.1530/jrf.0.0810301.

Ma L, Wang J, Zhang Y. Probing the characterization of the interaction of Aflatoxins B1 and G1 with Calf Thymus DNA In Vitro. Toxins (Basel). 2017;9(7):209. http://dx.doi.org/10.3390/toxins9070209. PMid:28671585.

Machtinger R, Gaskins AJ, Racowsky C, Mansur A, Adir M, Baccarelli AA, Calafat AM, Hauser R. Urinary concentrations of biomarkers of phthalates and phthalate alternatives and IVF outcomes. Environ Int. 2018;111:23-31. http://dx.doi.org/10.1016/j.envint.2017.11.011. PMid:29161633.

Manikkam M, Tracey R, Guerrero-Bosagna C, Skinner MK. Plastics derived endocrine disruptors (BPA, DEHP and DBP) induce epigenetic transgenerational inheritance of obesity, reproductive disease and sperm epimutations. PLoS One. 2013;8(1):e55387. http://dx.doi.org/10.1371/journal.pone.0055387. PMid:23359474.

Mann U, Shiff B, Patel P. Reasons for worldwide decline in male fertility. Curr Opin Urol. 2020;1(3):296301. http://dx.doi.org/10.1097/MOU.0000000000000745. PMid:32168194.

Maravilla-Galván R, Fierro R, González-Márquez H, Gómez-Arroyo S, Jiménez I, Betancourt M. Effects of atrazine and fenoxaprop-ethyl on capacitation and the acrosomal reaction in boar sperm. Int J Toxicol. 2009;28(1):24-32. http://dx.doi.org/10.1177/1091581809333138. PMid:19482828.

Martine B, Marie-Jeanne T, Cendrine D, Fabrice A, Marc C. Assessment of Adult Human Exposure to Phthalate Esters in the Urban Centre of Paris (France). Bull Environ Contam Toxicol. 2013;90(1):91-6. http://dx.doi.org/10.1007/s00128-012-0859-5. PMid:23090363.

Marzano G, Mastrorocco A, Zianni R, Mangiacotti M, Chiaravalle AE, Lacalandra GM, Minervini F, Cardinal A, Macciocca M, Vicenti R, Fabbri R, Hinrichs K, Dell'Aquila ME, Martino NA. Altered morphokinetics in equine embryos from oocytes exposed to DEHP during IVM. Mol Reprod Dev. 2019;86(10):1388-404. http://dx.doi.org/10.1002/mrd.23156. PMid:31025442.

McBirney M, King SE, Pappalardo M, Houser E, Unkefer M, Nilsson E, Sadler-Riggleman I, Beck D, Winchester P, Skinner MK. Atrazine induced epigenetic transgenerational inheritance of disease, lean phenotype and sperm epimutation pathology biomarkers. PLoS One. 2017;12(9):e0184306. http://dx.doi.org/10.1371/journal.pone.0184306. PMid:28931070.

McKee RH, Butala JH, David RM, Gans G. NTP center for the evaluation of risks to human reproduction reports on phthalates: addressing the data gaps. Reprod Toxicol. 2004;18(1):1-22. http://dx.doi.org/10.1016/j.reprotox.2003.09.002. PMid:15013060.

Meeker JD, Ehrlich S, Toth TL, Wright DL, Calafat AM, Trisini AT, Ye X, Hauser R. Semen quality and sperm DNA damage in relation to urinary bisphenol A among men from an infertility clinic. Reprod Toxicol. 2010;30(4):532-9. http://dx.doi.org/10.1016/j.reprotox.2010.07.005. PMid:20656017.

Meissonnier GM, Pinton P, Laffitte J, Cossalter A-M, Gong YY, Wild CP, Bertin G, Galtier P, Oswald IP. Immunotoxicity of aflatoxin B1: impairment of the cell-mediated response to vaccine antigen and modulation of cytokine expression. Toxicol Appl Pharmacol. 2008;231(2):142-9. http://dx.doi.org/10.1016/j.taap.2008.04.004. PMid:18501398.

Monson M, Cardona C, Coulombe R, Reed K. Hepatic Transcriptome Responses of Domesticated and Wild Turkey Embryos to Aflatoxin B1. Toxins (Basel). 2016;8(1):16. http://dx.doi.org/10.3390/toxins8010016. PMid:26751476.

Moyer B, Hixon ML. Reproductive effects in F1 adult females exposed in utero to moderate to high doses of mono-2-ethylhexylphthalate (MEHP). Reprod Toxicol. 2012;34(1):43-50. http://dx.doi.org/10.1016/j.reprotox.2012.02.006. PMid:22401849.

Nduka U, Ibeh NI, Oluwafemi F. A Study on the Impact of Aflatoxin on Human Reproduction. Afr J Reprod Health. 2001;5(1):106-10. http://dx.doi.org/10.2307/3583204. 
Net S, Delmont A, Sempéré R, Paluselli A, Ouddane B. Reliable quantification of phthalates in environmental matrices (air, water, sludge, sediment and soil): A review. Sci Total Environ. 2015a;515516:162-80. http://dx.doi.org/10.1016/j.scitotenv.2015.02.013. PMid:25723871.

Net S, Sempéré R, Delmont A, Paluselli A, Ouddane B. Occurrence, fate, behavior and ecotoxicological state of phthalates in different environmental matrices. Environ Sci Technol. 2015b;49(7):4019-35. http://dx.doi.org/10.1021/es505233b. PMid:25730609.

Niermann S, Rattan S, Brehm E, Flaws JA. Prenatal exposure to di-(2-ethylhexyl) phthalate (DEHP) affects reproductive outcomes in female mice. Reprod Toxicol. 2015;53:23-32. http://dx.doi.org/10.1016/j.reprotox.2015.02.013. PMid:25765777.

Oliva R, Castillo J, Estanyol J, Ballescà J. Human sperm chromatin epigenetic potential: genomics, proteomics, and male infertility. Asian J Androl. 2015;17(4):601-609. http://dx.doi.org/10.4103/1008682X.153302.

Pant N, Pant A, Shukla M, Mathur N, Gupta Y, Saxena D. Environmental and experimental exposure of phthalate esters: the toxicological consequence on human sperm. Hum Exp Toxicol. 2011;30(6):50714. http://dx.doi.org/10.1177/0960327110374205. PMid:20551087.

Parra-Forero LY, Veloz-Contreras A, Vargas-Marín S, Mojica-Villegas MA, Alfaro-Pedraza E, UriósteguiAcosta M, Hernández-Ochoa I. Alterations in oocytes and early zygotes following oral exposure to di(2-ethylhexyl) phthalate in young adult female mice. Reprod Toxicol. 2019;90:53-61. http://dx.doi.org/10.1016/j.reprotox.2019.08.012. PMid:31442482.

Peighambarzadeh S, Safi S, Shahtaheri S, Javanbakht M, Rahimi Forushani A. Rahimi Forushani a. Presence of atrazine in the biological samples of cattle and its consequence adversity in human health. Iran J Public Health. 2011;40(4):112-21. PMid:23113110.

Perry MJ. Effects of environmental and occupational pesticide exposure on human sperm: A systematic review. Hum Reprod Update. 2008;14(3):233-42. http://dx.doi.org/10.1093/humupd/dmm039. PMid:18281240.

Petersen JH, Breindahl T. Plasticizers in total diet samples, baby food and infant formulae. Food Addit Contam. 2000;17(2):133-41. http://dx.doi.org/10.1080/026520300283487. PMid:10793844.

Pflieger-Bruss S, Schuppe H-C, Schill W-B. The male reproductive system and its susceptibility to endocrine disrupting chemicals. Andrologia. 2004;36(6):337-45. http://dx.doi.org/10.1111/j.14390272.2004.00641.x. PMid:15541049.

Pure Strategies. Sources of phthalates in dairy farm equipment. Prepared for environmental health strategy center and the coalition for safer food processing \& packaging [Internet] Pure Strategies; 2018 [cited 2020 June 23]. Available from: http://kleanupkraft.org/Phthalates-Farm-Equipment.pdf.

Raisuddin S, Singh KP, Zaidi SI, Paul BN, Ray PK. Immunosuppressive effects of aflatoxin in growing rats. Mycopathologia. 1993;124(3):189-94. http://dx.doi.org/10.1007/BF01103737. PMid:8022466.

Rajkovic A, Uyttendaele M, Debevere J. Computer aided boar semen motility analysis for cereulide detection in different food matrices. Int J Food Microbiol. 2007;114(1):92-9. http://dx.doi.org/10.1016/j.jfoodmicro.2006.09.031. PMid:17174428.

Ramalho-Santos J, Varum S, Amaral S, Mota PC, Sousa AP, Amaral A. Mitochondrial functionality in reproduction: from gonads and gametes to embryos and embryonic stem cells. Hum Reprod Update. 2009;15(5):553-72. http://dx.doi.org/10.1093/humupd/dmp016. PMid:19414527.

Rando OJ. Daddy issues: paternal effects on phenotype. Cell. 2012;151(4):702-8. http://dx.doi.org/10.1016/j.cell.2012.10.020. PMid:23141533.

Reyes-Moreno C, Boilard M, Sullivan R, Sirard MA. Characterization and Identification of Epididymal Factors That Protect Ejaculated Bovine Sperm During In Vitro Storage. Biol Reprod. 2002;66(1):15966. http://dx.doi.org/10.1095/biolreprod66.1.159. PMid:11751277.

Rhind SM, Kyle CE, Telfer G, Duff El, Smith A. Alkyl phenols and diethylhexyl phthalate in tissues of sheep grazing pastures fertilized with sewage sludge or inorganic fertilizer. Environ Health Perspect. 2005;113(4):447-53. http://dx.doi.org/10.1289/ehp.7469. PMid:15811823.

Ross MK, Jones TL, Filipov NM. Disposition of the Herbicide 2-Chloro-4-(ethylamino)-6-(isopropylamino)s-triazine (Atrazine) and its major metabolites in mice: A liquid chromatography / mass spectrometry analysis of urine. Plasma, and Tissue Levels. 2009;37(4):776-86. http://dx.doi.org/10.1124/dmd.108.024927. PMid:19116264.

Roth Z. Symposium review: Reduction in oocyte developmental competence by stress is associated with alterations in mitochondrial function1. J Dairy Sci. 2018;101(4):3642-54. http://dx.doi.org/10.3168/jds.2017-13389. PMid:29395145. 
Sánchez-Peña LC, Reyes BE, López-Carrillo L, Recio R, Morán-Martínez J, Cebrián ME, Quintanilla-Vega B. Organophosphorous pesticide exposure alters sperm chromatin structure in Mexican agricultural workers. Toxicol Appl Pharmacol. 2004;196(1):108-13. http://dx.doi.org/10.1016/j.taap.2003.11.023. PMid:15050412.

Sant KE, Dolinoy DC, Jilek JL, Sartor MA, Harris C. Mono-2-ethylhexyl phthalate disrupts neurulation and modifies the embryonic redox environment and gene expression. Reprod Toxicol. 2016;63:32-48. http://dx.doi.org/10.1016/j.reprotox.2016.03.042. PMid:27167697.

Saradha B, Mathur PP. Effect of environmental contaminants on male reproduction. Environ Toxicol Pharmacol. 2006;21(1):34-41. http://dx.doi.org/10.1016/j.etap.2005.06.004. PMid:21783636.

Schenzel J, Forrer H-R, Vogelgsang S, Hungerbühler K, Bucheli TD. Mycotoxins in the Environment: I. Production and Emission from an Agricultural Test Field. Environ Sci Technol. 2012;46(24):13067-75. http://dx.doi.org/10.1021/es301557m. PMid:23145781.

Sergerie M, Laforest G, Bujan L, Bissonnette F, Bleau G. Sperm DNA fragmentation: threshold value in male fertility. Hum Reprod. 2005;20(12):3446-51. http://dx.doi.org/10.1093/humrep/dei231. PMid:16085665.

Severi-Aguiar GDC, Silva-Zacarin ECM. Effects of herbicide atrazine in experimental animal models. In: Hasaneen MN. Herbicides: Properties, synthesis and control of weeds. Rijeka: InTech; 2011. p. 28596.

Shen HM, Shi CY, Lee HP, Ong CN. Aflatoxin B1-induced lipid peroxidation in rat liver. Toxicol Appl Pharmacol. 1994;127(1):145-50. http://dx.doi.org/10.1006/taap.1994.1148. PMid:8048046.

Shuaib FMB, Ehiri J, Abdullahi A, Williams JH, Jolly PE. Reproductive health effects of aflatoxins: a review of the literature. Reprod Toxicol. 2010;29(3):262-70. http://dx.doi.org/10.1016/j.reprotox.2009.12.005. PMid:20045048.

Siddeek B, Mauduit C, Simeoni U, Benahmed M. Sperm epigenome as a marker of environmental exposure and lifestyle, at the origin of diseases inheritance. Mutat Res Mutat Res. 2018;778:38-44. http://dx.doi.org/10.1016/j.mrrev.2018.09.001. PMid:30454681.

Silva MJ, Reidy JA, Herbert AR, Preau JL Jr, Needham LL, Calafat AM. Detection of phthalate metabolites in human amniotic fluid. Bull Environ Contam Toxicol. 2004;72(6):1226-31. http://dx.doi.org/10.1007/s00128-004-0374-4. PMid:15362453.

Simões R, Feitosa WB, Siqueira AFP, Nichi M, Paula-Lopes FF, Marques MG, Peres MA, Barnabe VH, Visintin JA, Assumpção ME. Influence of bovine sperm DNA fragmentation and oxidative stress on early embryo in vitro development outcome. Reproduction. 2013;146(5):433-41. http://dx.doi.org/10.1530/REP-13-0123. PMid:23940385.

Skinner MK, Nilsson E, Sadler-Riggleman I, Beck D, Ben Maamar M, McCarrey JR. Transgenerational sperm DNA methylation epimutation developmental origins following ancestral vinclozolin exposure. Epigenetics. 2019;14(7):721-39. http://dx.doi.org/10.1080/15592294.2019.1614417. PMid:31079544.

Sotomayor RE, Sega GA. Unscheduled DNA synthesis assay in mammalian spermatogenic cells: an update. Environ Mol Mutagen. 2000;36(4):255-65. http://dx.doi.org/10.1002/10982280(2000)36:4<255::AID-EM1>3.0.CO;2-O. PMid:11152558.

Staub C, Johnson L. Review: spermatogenesis in the bull. Animal. 2018;12(s1):s27-35. http://dx.doi.org/10.1017/S1751731118000435. PMid:29882505.

Storvik M, Huuskonen P, Kyllönen T, Lehtonen S, El-Nezami H, Auriola S, Pasanen M. Aflatoxin B1 - a potential endocrine disruptor - up-regulates CYP19A1 in JEG-3 cells. Toxicol Lett. 2011;202(3):161-7. http://dx.doi.org/10.1016/j.toxlet.2011.01.028. PMid:21296134.

Strosnider H, Azziz-Baumgartner E, Banziger M, Bhat RV, Breiman R, Brune M-N, DeCock K, Dilley A, Groopman J, Hell K, Henry SH, Jeffers D, Jolly C, Jolly P, Kibata GN, Lewis L, Liu X, Luber G, McCoy L, Mensah P, Miraglia M, Misore A, Njapau H, Ong CN, Onsongo MT, Page SW, Park D, Patel M, Phillips T, Pineiro M, Pronczuk J, Rogers HS, Rubin C, Sabino M, Schaafsma A, Shephard G, Stroka J, Wild C, Williams JT, Wilson D. Workgroup Report: Public Health Strategies for Reducing Aflatoxin Exposure in Developing Countries. Environ Health Perspect. 2006;114(12):1898-903. http://dx.doi.org/10.1289/ehp.9302. PMid:17185282.

Supriya C, Girish BP, Reddy PS. Aflatoxin B1-Induced Reproductive Toxicity in Male Rats: Possible Mechanism of Action. Int J Toxicol. 2014;33(3):155-61. http://dx.doi.org/10.1177/1091581814530764. PMid:24728861. 
Swan SH, Kruse RL, Liu F, Barr DB, Drobnis EZ, Redmon JB, Wang C, Brazil C, Overstreet JW. Semen Quality in Relation to Biomarkers of Pesticide Exposure. Environ Health Perspect. 2003;111(12):147884. http://dx.doi.org/10.1289/ehp.6417. PMid:12948887.

Tavares RS, Escada-Rebelo S, Correia M, Mota PC, Ramalho-Santos J. The non-genomic effects of endocrine-disrupting chemicals on mammalian sperm. Reproduction. 2016;151(1):R1-13. http://dx.doi.org/10.1530/REP-15-0355. PMid:26585413.

Thouas GA, Trounson AO, Wolvetang EJ, Jones GM. Mitochondrial Dysfunction in Mouse Oocytes Results in Preimplantation Embryo Arrest in Vitro. Biol Reprod. 2004;71(6):1936-42. http://dx.doi.org/10.1095/biolreprod.104.033589. PMid:15286028.

Toft G, Jönsson BAG, Lindh CH, Jensen TK, Hjollund NH, Vested A, Bonde JP. Association between Pregnancy Loss and Urinary Phthalate Levels around the Time of Conception. Environ Health Perspect. 2011;120(3):458-63. http://dx.doi.org/10.1289/ehp.1103552. PMid:22113848.

Tomita I, Nakamura Y, Aoki N, Inui N. Mutagenic/carcinogenic potential of DEHP and MEHP. Environ Health Perspect. 1982;45:119-25. http://dx.doi.org/10.1289/ehp.8245119. PMid:6814903.

Tranfo G, Caporossi L, Paci E, Aragona C, Romanzi D, De Carolis C, De Rosa M, Capanna S, Papaleo B, Pera A. Urinary phthalate monoesters concentration in couples with infertility problems. Toxicol Lett. 2012;213(1):15-20. http://dx.doi.org/10.1016/j.toxlet.2011.11.033. PMid:22197707.

Treinen KA, Dodson WC, Heindel JJ. Inhibition of FSH-stimulated cAMP accumulation and progesterone production by mono(2-ethylhexyl) phthalate in rat granulosa cell cultures. Toxicol Appl Pharmacol. 1990;106(2):334-40. http://dx.doi.org/10.1016/0041-008X(90)90252-P. PMid:2175055.

Uppangala S, Pudakalakatti S, D'souza F, Salian SR, Kalthur G, Kumar P, Atreya H, Adiga SK. Influence of sperm DNA damage on human preimplantation embryo metabolism. Reprod Biol. 2016;16(3):234-41 http://dx.doi.org/10.1016/j.repbio.2016.07.004. PMid:27492188.

Verma RJ, Nair A. Ameliorative effect of vitamin E on aflatoxin-induced lipid peroxidation in the testis of mice. Asian J Androl. 2001;3(3):217-21. PMid:11561193.

Verma RJ. Aflatoxin cause DNA damage. Int J Hum Genet. 2004;4(4):231-6. http://dx.doi.org/10.1080/09723757.2004.11885899.

Virro MR, Larson-Cook KL, Evenson DP. Sperm chromatin structure assay (SCSA $®$ ) parameters are related to fertilization, blastocyst development, and ongoing pregnancy in in vitro fertilization and intracytoplasmic sperm injection cycles. Fertil Steril. 2004;81(5):1289-95. http://dx.doi.org/10.1016/j.fertnstert.2003.09.063. PMid:15136092.

Wang T, Han J, Duan X, Xiong B, Cui X-S, Kim N-H, Liu HL, Sun SC. The toxic effects and possible mechanisms of Bisphenol A on oocyte maturation of porcine in vitro. Oncotarget. 2016;7(22):3255465. http://dx.doi.org/10.18632/oncotarget.8689. PMid:27086915.

Wang W, Craig ZR, Basavarajappa MS, Hafner KS, Flaws JA. Mono-(2-ethylhexyl) phthalate induces oxidative stress and inhibits growth of mouse ovarian antral follicles. Biol Reprod. 2012;87(6):152. http://dx.doi.org/10.1095/biolreprod.112.102467. PMid:23077170.

Wei Y, Schatten H, Sun Q-Y. Environmental epigenetic inheritance through gametes and implications for human reproduction. Hum Reprod Update. 2015;21(2):194-208. http://dx.doi.org/10.1093/humupd/dmu061. PMid:25416302.

Wei Y, Yang CR, Wei YP, Zhao ZA, Hou Y, Schatten H, Sun QY. Paternally induced transgenerational inheritance of susceptibility to diabetes in mammals. Proc Natl Acad Sci USA. 2014;111(5):1873-8. http://dx.doi.org/10.1073/pnas.1321195111. PMid:24449870.

Williams JH, Phillips TD, Jolly PE, Stiles JK, Jolly CM, Aggarwal D. Human aflatoxicosis in developing countries: a review of toxicology, exposure, potential health consequences, and interventions. Am J Clin Nutr. 2004;80(5):1106-22. http://dx.doi.org/10.1093/ajcn/80.5.1106. PMid:15531656.

Wirbisky-Hershberger SE, Sanchez OF, Horzmann KA, Thanki D, Yuan C, Freeman JL. Atrazine exposure decreases the activity of DNMTs, global DNA methylation levels, and dnmt expression. Food Chem Toxicol. 2017;109(Pt 1):727-34. http://dx.doi.org/10.1016/j.fct.2017.08.041. PMid:28859886.

Wiser A, Sachar S, Ghetler Y, Shulman A, Breitbart H. Assessment of sperm hyperactivated motility and acrosome reaction can discriminate the use of spermatozoa for conventional in vitro fertilisation or intracytoplasmic sperm injection: preliminary results. Andrologia. 2014;46(3):313-5. http://dx.doi.org/10.1111/and.12068. PMid:23356546.

Yagi Y, Nakamura Y, Tomita I, Tsuchikawa K, Shimoi N. Teratogenic potential of di- and mono-(2ethylhexyl)phthalate in mice. J Environ Pathol Toxicol. 1980;4(2-3):533-44. PMid:7462917. 
Yuan S, Wu B, Yu Z, Fang J, Liang N, Zhou M, Huang C, Peng X. The mitochondrial and endoplasmic reticulum pathways involved in the apoptosis of bursa of Fabricius cells in broilers exposed to dietary aflatoxin B1. Oncotarget. 2016;7(40):65295-306. http://dx.doi.org/10.18632/oncotarget.11321. PMid:27542244.

Zama AM, Bhurke A, Uzumcu M. Effects of Endocrine-disrupting Chemicals on Female Reproductive Health. Open Biotechnol J. 2016;10(1):54-75. http://dx.doi.org/10.2174/1874070701610010054.

Zamkowska D, Karwacka A, Jurewicz J, Radwan M. Environmental exposure to non-persistent endocrine disrupting chemicals and semen quality: an overview of the current epidemiological evidence. Int J Occup Med Environ Health. 2018;31(4):377-414. http://dx.doi.org/10.13075/ijomeh.1896.01195. PMid:30160090.

Zhang T, Li L, Qin X-S, Zhou Y, Zhang X-F, Wang L-Q, De Felici M, Chen H, Qin GQ, Shen W. Di-(2ethylhexyl) phthalate and bisphenol A exposure impairs mouse primordial follicle assembly in vitro. Environ Mol Mutagen. 2014;55(4):343-53. http://dx.doi.org/10.1002/em.21847. PMid:24458533.

Zhang X-F, Zhang L-J, Li L, Feng Y-N, Chen B, Ma J-M, Huynh E, Shi QH, De Felici M, Shen W. Diethylhexyl phthalate exposure impairs follicular development and affects oocyte maturation in the mouse. Environ Mol Mutagen. 2013;54(5):354-61. http://dx.doi.org/10.1002/em.21776. PMid:23625783.

Zhang Y, Wang T, Lan M, Zang XW, Li YL, Cui XS, Kim NH, Sun SC. Melatonin protects oocytes from MEHP exposure-induced meiosis defects in porcine. Biol Reprod. 2018;98(3):286-98. http://doi.org//10.1093/biolre/iox185

\section{Author contribution:}

ZR, AKE and DK: Conceptualization, Writing - original draft, Writing - review \& editing. 